\title{
Legal Protection of Sami Traditional Livelihoods from the Adverse Impacts of Mining: A Comparison of the Level of Protection Enjoyed by Sami in Their Four Home States
}

\section{Timo Koivurova ${ }^{\star}$,}

Research Professor, Director, Northern Institute for Environmental and Minority Law, Arctic Centre, University of Lapland, Rovaniemi, Finland

Vladimir Masloboev,

Professor, Institute of Industrial Ecology Problems in the North, Kola Science Centre of the Russian Academy of Sciences, Apatity, Russia

Kamrul Hossain,

Senior Researcher, Northern Institute for Environmental and Minority Law, Arctic Centre, University of Lapland and Adjunct Professor, Faculty of Law, University of Lapland, Rovaniemi, Finland

Vigdis Nygaard,

Senior Research, Northern Research Institute, Alta, Norway

Anna Petrétei,

Researcher, PhD student, Northern Institute for Environmental and Minority Law, Arctic Centre, University of Lapland, Rovaniemi, Finland

Svetlana Vinogradova,

Researcher, Kola Science Centre of the Russian Academy of Sciences, Apatity, Russia

\begin{abstract}
As a consequence of the growing global need for minerals, extractive industries are continuously expanding. In the North, together with several environmental problems such as climate change, this poses a real threat to the traditional livelihoods of Sami people. The article examines how the rights of Sami indigenous people are protected against adverse impacts of mining activities. The relevant national legislation is analyzed in all the four countries where Sami are present. It is specifically examined how the main mining act in each country protects the right of Sami people to their traditional livelihoods. Finally, the article sheds light on the actual effectiveness of the legal
\end{abstract}

${ }^{\star}$ Correspondence to: Timo Koivurova, Research Professor, Director, Northern Institute for Environmental and Minority Law, Arctic Centre, University of Lapland, FI-96300 Rovaniemi, Finland. Email: timo.koivurova@ulapland.fi 


\section{T. Koivurova et al.}

regulation. This is done by analyzing the results of interviews conducted with relevant actors and stakeholders in the mining industry.

Keywords: indigenous peoples; Sami rights; mining

Received: October 2014; Accepted: January 2015; Published: March 2015

\section{Introduction}

In this article, our first aim is to examine how Sami ${ }^{1}$ people are currently protected against the harmful impacts of mining in each of the four countries - Finland, Norway, Russia and Sweden - by way of legal tools. ${ }^{2}$ Secondly, we aim to see whether these different legal systems can benefit from each other, as well as whether the current mining law systems provide enough protection for indigenous Sami from the viewpoint of international standards. We explain the general laws that apply to mining and then the main mining laws in force in each country. In particular, we study how these mining codes take indigenous rights specifically into account. As reindeer herding is the livelihood generally the most affected by mining activities, the protection of the right to reindeer herding is specifically examined. After studying the theoretical legal background, we look to shed light on the effectiveness of the implementation of the mining codes in each of the four countries, as well as the future perspectives of mining on Sami lands from the viewpoint of the mining sector. In order to do so, we employ the findings of anonymous, semi-structured interviews we conducted with relevant actors such as mining companies, environmental impact assessment consultants, authority representatives, and the reflection of Sami representatives that. ${ }^{3}$ The core issue in this article is: how strong a degree of legal protection Sami enjoy in their respective home countries against the adverse impacts of mining.

\section{Protection of traditional Sami livelihoods from adverse mining impacts}

\subsection{Introduction}

The term livelihood refers to activities that have primary production as the source of income. Traditionally, the Sami have pursued a variety of nature-based livelihoods connected to their lands and territories, such as fishing, trapping, ${ }^{4}$ small scale family forestry, agriculture, gathering of wild berries and other natural products, together with handicraft-like manufacture of traditional articles. However, the most common means of livelihood has been semi-nomadic reindeer herding. ${ }^{5}$ Even though these traditional ways of livelihood are still important components for their economy, ${ }^{6}$ the Sami of today are also engaged in a variety of other occupations that modern society offers. Many Sami still, for instance, conduct traditional fishing, but not as the sole source of household income. By fishing they can meet their everyday nutritional needs, whereas for some riverside populations it also brings a small but extra income. For example, in Inari in Northern Finland some commercial Sami fishing still takes 
place and provides important support to the economy of the local community. While fishing is nowadays regarded as the secondary occupation, changed circumstances have led to other modern income generating activities such as tourism filling the gaps in the economy. This seems profitable, particularly amongst the Nordic Sami, many of which have built holiday villages or established campsite nearby their homes. ${ }^{7}$ In addition, they are also involved in the commercial utilization of uncultivated lands, and many are also employed in other parts of the labor market. ${ }^{8}$ Thus, in the Sami community it would seem that traditional livelihood practices coexist with modern money earning activities.

As a distinct Sami livelihood however, reindeer herding has remained the unique economic and cultural emblem for the Sami people. To the outside world, reindeer herding and Sami culture are often seen as inseparable despite the fact that only a small number of Sami are currently involved in the herding industry. ${ }^{9}$ However, for traditional, environmental, cultural and political reasons, it has become the crucial aspect of Sami livelihood. ${ }^{10}$ Altogether, approximately 6,500 Sami are involved in traditional reindeer herding activities. ${ }^{11}$ Of these, around 2,800 are actively involved on a full-time basis, ${ }^{12}$ while the others are engaged in a diverse range of traditional and non-traditional activities which relate to reindeer herding.

The Sami do not have to compete with the majority population in reindeer herding as the right to reindeer herding is reserved only for Sami in both Norway and Sweden. About $10 \%$ of Swedish Sami are engaged in reindeer herding activities. The size of the herding area is about $240,000 \mathrm{~km}^{2}$, which represents over $50 \%$ of Sweden's land area. The biggest part of the herding area is located in the Norrbotten ${ }^{13}$ and Västerbotten regions. ${ }^{14}$ Unfortunately for the Sami, most of the Swedish mineral deposits can also be found in these areas, thus causing obvious land use conflicts. ${ }^{15}$ Traditional Sami livelihoods in Norway are reindeer herding, fjord fishing and farming. ${ }^{16}$ In Norway, reindeer herding can only be conducted by people of Sami origin. Only those who have the right to a reindeer earmark can conduct reindeer husbandry in the Sami reindeer herding area. ${ }^{17}$ The right to a reindeer tag requires that the person is a Sami, and they themselves, their parents or their grandparents have or have previously had reindeer herding as their main occupation. ${ }^{18}$ Reindeer herding employs approximately 3000 people. ${ }^{19}$ This employment is the most intensive in the county of Finnmark, where practically all of the land is used for seasonal herding. ${ }^{20}$ Generally, the Sami population uses approximately $40 \%$ of the area on the Norwegian mainland for reindeer herding purposes. ${ }^{21}$ The number of people directly engaged in reindeer herding can be extended by other family members who are partly involved in related businesses like handicrafts, sales and tourism. Most reindeer herder households have members with other work in the public or private sector. Reindeer herding is dependent on state subsidies and has low financial value creation, however reindeer herding is considered the most important Sami cultural identity marker, even though most Sami people have other livelihoods.

Although in Finland and Russia no restrictions are imposed on people other than Sami to exercise reindeer herding, it is largely considered as a significant part of Sami culture. $^{22}$ The herding knowledge is kept intact and transmitted from one generation 


\section{T. Koivurova et al.}

to the next through a rich vocabulary of animals, landscape characteristics and climatic conditions. ${ }^{23}$ In Finland, approximately $10 \%$ of Sami practice reindeer herding, which is seen as a fundamental part of Sami culture. Besides reindeer herding, the most commonly pursued Sami livelihoods are generally coastal fishing and fur trapping. Moreover, traditional Sami handicrafts which were originally intended for domestic use, are produced and sold in large numbers, thus contributing to their means of earning a living.

The main livelihood of the Sami in Russia is reindeer herding. On the Kola Peninsula, reindeer herding is concentrated in two big enterprises. ${ }^{24}$ Both companies are complex agricultural enterprises and own $90 \%$ of all Kola reindeer. The majority of Sami people work at these enterprises as employees, where they constitute only $17 \%$ of the total staff (all indigenous people, including Komi and Nenets constitute $35 \%) .{ }^{25}$ The main income for Sami families is either the salary from reindeer herding enterprises or from other organizations where they work. ${ }^{26}$ When discussing Russian Sami livelihoods, it is very important to mention the obschina. This is a traditional form of organization for indigenous peoples in Russia, which allows them to revive and develop their culture, traditions and traditional nature-based livelihoods. Unfortunately, in the Murmansk region obschinas are actively created, but poorly developed. Currently, 23 obschinas of indigenous small peoples are registered in the region, the main activities of which are handicrafts and fisheries. It must be noted that plots for fishing are not reserved for obschinas, and they participate only in the process of quota allocation. Amongst all the obschinas only three deal with reindeer herding, however these do not play an important role in the regional reindeer herding activities, as they have small herds and use only $4,5 \%$ of the total pasture. ${ }^{27}$

Although reindeer herding is definitely the best known Sami livelihood, the dynamics of socio-economic and technological change have resulted in the transformation of the daily life of the reindeer herders. Their old life style has been replaced by permanent settlement, and reindeer husbandry has become an industry. ${ }^{28}$ Nowadays, modern means are used in reindeer herding activities. Mechanized vehicles such as snowmobiles and helicopters are being used for herding and other work connected with the industry. ${ }^{29}$ This is due to adapting the industry to the market economy. Today, marketing cooperatives are organized, with modern slaughter-houses and reindeer products being placed in shops for sale. With the market economy becoming dominant, herding took on a larger perspective and the development made herding as an industry become directed towards production for sale and economic profitability. $^{30}$

Today, one of the major threats to the reindeer herding industry is the gradually increasing mining boom. More and more mining activities are operating in these Sami areas, so posing a clear threat to Sami reindeer herding which requires a lot of space, and also to other traditional livelihoods. Traditional livelihoods are understood here in a manner similar to that of the Human Rights Committee that monitors the only international legal treaty that provides (at least potential) protection to Sami in all of the four countries, in regard to safeguarding their 
traditional livelihoods. As The Committee provided in its General Comment No. 23:

3.2. The enjoyment of the rights to which Article 27 relates does not prejudice the sovereignty and territorial integrity of a State party. At the same time, one or other aspect of the rights of individuals protected under that article-for example, to enjoy a particular culture - may consist in a way of life which is closely associated with territory and use of its resources. This may particularly be true of members of indigenous communities constituting a minority. ${ }^{31}$

In a case concerning the Finnish Sami, The Committee has also clarified that traditional livelihoods need not be done as they were done in the past, but can be adapted to changing circumstances and developing technologies. ${ }^{32}$

\subsection{Protection of Sami traditional livelihoods}

Traditional livelihoods of Sami, especially reindeer herding, enjoy various kinds of protection from the four respective legal systems. The protection of Sami traditional livelihoods takes place via different legal means in different legal systems. There is also other legislation that holds relevance for whether the Sami receive legal protection.

It would be clearest if the Sami were to enjoy full ownership over the land or resource rights in regard to conducting their traditional livelihoods as is the case in some other regions, for example like some parts of the Inuit governed Nunavut region. This however is not the case, even in Norway's Finnmark county. The Sami Parliament also has influence on how non-cultivated areas of Finnmark are developed. Although the Finnmark Act enhances Sami rights in Finnmark, it has also been criticized as not really implementing ILO 169 correctly, ${ }^{33}$ given that all rights are non-discriminatory between Sami and non-Sami in the region. Hence, even in the case of Finnmark, Sami have no clear ownership rights over the land for the purposes of practicing their traditional livelihoods, especially reindeer herding. Another important change in the Norwegian legal framework was the adoption of a new Planning and Building Act in 2010. This strengthens the Municipality's role as the planning authority to safeguard the foundations of Sami culture, business and society when it comes to changes in land use within the municipal territory. ${ }^{34}$ This means for instance that the Municipality can stop a mineral project. The law also gives the Sami Parliament authority to lodge an objection. $^{35}$

Reindeer herding enjoys immemorial use right status both in Norway and Sweden. In Norway, it is nowadays evident that reindeer herding is no longer enjoyed as a collective right, that is, by the Sami as a group. Since the right to herd reindeer can be obtained through customary and immemorial usage, a siida ${ }^{36}$ may be able to win this right at the cost of other reindeer herding Sami. ${ }^{37}$ By strengthening the collectivist feature of Sami reindeer herding rights, there has been a development in how one may view the judicial basis of reindeer herding, and therefore also the type of protection reindeer herders have against other interests. ${ }^{38}$ There can no longer be 


\section{T. Koivurova et al.}

any doubt that the legal basis of reindeer husbandry rests upon customary and immemorial usage.

In Sweden, according to the Reindeer Herding Act, ${ }^{39}$ persons of Sami origin have the right to use land and water resources to take care of themselves and their reindeer. For the reindeer herding rights to apply, the person must however be a member of a Sami village. ${ }^{40}$ The rights are exclusive for the Sami people (considered as "indigenous peoples") and are based on immemorial prescription. ${ }^{41}$ In 2011 however, the Swedish Supreme Court took a new course by stating that the Sami reindeer herding right on winter-pasture areas is based on customary law and not immemorial prescription, as had been previously applied. ${ }^{42}$

In Finland, reindeer herding as a right for all is stipulated in Section 3-The right to practice reindeer herding: "(1) Subject to the restrictions provided in this Act, reindeer herding may be practiced in the reindeer herding area irrespective of land ownership or possession rights." Hence, it is a weak use right and can be trumped by other rights.

In Russia, reindeer herding as a branch of agriculture is regulated by relevant legislation. At the same time, reindeer herding is declared to be a traditional Sami livelihood and is included in the "Integrated List of Types of Traditional Economic Activities of the Numerically Small Indigenous Peoples of the Russian Federation."43 Moreover, the Regional Law "On reindeer herding in the Murmansk region"44 is adopted, which regulates the activity of large enterprises. This means that state support and protection is guaranteed for reindeer herding.

The Russian Federation has a multi-level legal system, including federal legislation, legislation of federal entities, and local legislation. The federal legal framework for the protection and promotion of the rights of indigenous peoples in Russia is extensive and consists of three framework laws specifically addressing indigenous peoples: "On Guarantees of the Rights of Numerically Small Indigenous Peoples of the Russian Federation,"45 passed in 1999; "On Territories of Traditional Nature Use of the Numerically Small Indigenous Peoples of the North, Siberia and the Far East of the Russian Federation," 46 adopted in 2001.; and "On General Principles of Organization of Obshchina of Numerically Small Indigenous Peoples of the North, Siberia and the Far East of the Russian Federation,"47 adopted in 2000. The guarantees set out in the federal legislation include the group and individual rights of indigenous peoples to free-of-charge use of land and renewable natural resources in territories which they have traditionally occupied and where they engage in traditional economic activities. They also include the rights to establish self-government bodies in places of compact settlement and to form communities and other organizations; the right to reform their educational institutions according to their traditional way of life; the right to receive compensation for damage to their traditional environment due to industrial activities; the right to have courts consider customary law in as far as it does not contradict federal or regional legislation; and other entitlements. However, while the guarantees set out in these federal laws are substantial, there has been widespread criticism of the lack of effective implementation. ${ }^{48}$ 
In February 2009 the federal Government adopted a Concept Paper on the Sustainable Development of Indigenous Peoples of the North, Siberia and the Far East of the Russian Federation, ${ }^{49}$ defining the federal policy from 2009 to 2025 for improving the socio-economic conditions, and protecting the traditional environments, way of life and cultural values of indigenous peoples; and specifying time frames and benchmarks for implementation. ${ }^{50}$

Regional legislation of the Murmansk region is represented by two laws: "On State support for Numerically Small Indigenous Peoples of the North, conducting traditional economic activities and crafts in the Murmansk region," 51 adopted by the Murmansk Regional Duma in 2008; and the Regional Law "On Reindeer herding in the Murmansk region" which was adopted in $2003 .{ }^{52}$ These laws fix the status of Sami as a Numerically Small Indigenous People of the Murmansk region, as well as confirming the regional mechanisms of state support and protection for their livelihood.

\section{Mining legislation and Sami rights in the respective countries}

Before describing the relevant national legislation, it is important to note that Sami traditional livelihoods are not only protected by legislative means. As it is explained below, in some of the counties the legal ground for Sami land rights, inter alia reindeer herding, is customary usage. The protection provided on the basis of customary use is independent of legislation. Each of the countries in question has a wide range of legal instruments regulating mining and related activities. However, in all countries there is one main legal act that governs mining. The main act in Finland is the Mining Act, ${ }^{53}$ in Sweden the Minerals Act, ${ }^{54}$ in Norway the Mineral Act, ${ }^{55}$ and in Russia the Law of the Russian Federation "On Subsoil." 56 Each of the main mining acts contains provisions concerning indigenous peoples.

According to the Swedish mining legislation, the Sami have the same status and rights as landowners in relation to mineral activities. Moreover, the Sami are holders of special rights and thus their interests have to be taken into account. Reindeer herding and mineral extraction are both regarded as national interests, however they typically compete in mine planning processes. According to the Minerals Act of Sweden, holders of special rights, including affected Sami villages, need to be involved during some stages of the grant processes of exploration permits and exploitation concessions. For instance, they are to be notified at the stage of exploitation and in the drafting of the work plan. ${ }^{57}$ This means involvement from a very early phase, as the work plan (containing the planned work, timetable and assessment of impacts) has to be prepared before the exploration work begins. During the concession stage, Sami villages take part in the environmental impact assessment (EIA) procedure.

Recent changes in the Swedish Minerals Act and Ordinance have strengthened the rights of the Sami. Since 1 August 2014, the Sami can require that the work plan is translated into the Sami language. Also, the amendment ensures that the affected parties receive the information they need to safeguard their rights against the permit holder. $^{58}$ 


\section{T. Koivurova et al.}

The Norwegian Mineral Act contains several provisions on Sami people, with special regard to the Finnmark area where Sami interests are particularly taken into account. ${ }^{59}$ The administration and use of mineral resources pursuant to the Act ensures that the foundations of Sami culture, commercial activity and social life are safeguarded. ${ }^{60}$ The Act shall be applied in accordance with the rules of international law relating to indigenous peoples and minorities, ${ }^{61}$ however, it is debated whether ILO Convention 169 is fully implemented by this section. ${ }^{62}$ During the process of searching for mineral resources in Finnmark, the searching party shall give notice not only to the landowner and user of the land, but they are also obliged to give written notice to the Sami Parliament, the Finnmarkseiendommen (the Finnmark Estate) where it is the landowner, and the relevant area and district boards for reindeer management. Whenever practically possible, the siidas shall be given oral notice. Notice shall be given as early as possible, and at the latest two weeks before a search is commenced. ${ }^{63}$ In the case of an exploration permit application in Finnmark, the Directorate of Mining shall inform the landowner, as well as the Sameting, the relevant area and district boards for reindeer management, and also the municipality of the permit. ${ }^{64}$ An exploring party shall not only give written notice of exploration to the Directorate of Mining, the landowner and the user of the land at least three weeks before work is begun, but also to the Sameting and the relevant area and district boards for reindeer management. Whenever practically possible, the siidas shall be given oral notice. ${ }^{65}$

The Norwegian Mineral Act contains a specific section ${ }^{66}$ related to applications for exploration in Finnmark. According to the provisions of this section, within the Finnmark area an exploration permit does not confer a right to undertake exploration or pilot extraction until the Directorate of Mining has granted a special permit for such activities. Exploring parties are obliged to take reasonable steps to obtain information about directly affected Sami interests in the area that is to be explored. A special permit may be refused when granting the application would be contrary to Sami interests. Special consideration shall be given to the interests of Sami culture, reindeer management, commercial activity, and social life. Once the application is granted, conditions may be imposed to safeguard these interests. When processing the application, the Directorate of Mining shall give the landowner, the Sami Parliament, the municipality, and the relevant area and district boards for reindeer management an opportunity to comment. If the Sami Parliament or the landowner opposes the granting of an application, the Ministry makes a decision. If in such cases the Ministry grants an application, an appeal to the King by the Sameting or the landowner has a suspensive effect. Pursuant to Section 58, in the Finnmark region the annual landowner fee may be extended by the Ministry.

During the drafting process of the Minerals Act, the Sami Parliament held several consultations with the Ministry of Commerce to influence the protection of Sami rights in the Act. However, the parties failed to come to an agreement and the Act was adopted without consent from the Sami Parliament. According to the Sami Parliament, the Minerals Act does not safeguard the obligations that the State has to the Sami as an indigenous people in accordance with human rights. ${ }^{67}$ One of the 
reasons for this conclusion is that Sami people outside Finnmark region cannot participate in the decision-making process to the same extent as those Sami in Finnmark - a right given by the Finnmark Act. Another reason is the lack of profit sharing mechanisms. The mining company is however obliged to pay an extended landowner fee of $0,25 \%$ of the sales to the landowner in Finnmark. ${ }^{68}$ This is in some cases referred to as an "indigenous fee," but the Sami Parliament claims to be the fee receiver, not the Finnmark Estate which represents all of the people in Finnmark. ${ }^{69}$

The Norwegian government adopted a Strategy for the Mineral Industry in March 2013 to make Norway a more attractive country for mineral activity. ${ }^{70}$ The strategy has a chapter on "Mineral activities in areas with Sami interests," "71 which stresses the obligations of the mining industry to follow the OECD guidelines for multinational companies, the "UN Guiding Principles on Business and Human Rights." It also presents some initiatives for competence building and the effects of mineral activities on reindeer husbandry and other Sami interests. As an answer to the critics from the Sami Parliament, the Strategy says that the Government will consider whether the Minerals Act should be amended with the inclusion of specific rules to protect Sami interests in connection with mineral operations outside Finnmark, although it is still unclear to what extent this consideration will be followed up.

In Finland, Sami rights are relatively strongly protected by the Mining Act. The Act states that the activities referred to in the Act shall be adapted in the Sami Homeland, so as to secure the rights of the Sami as an indigenous people. ${ }^{72}$ The Act contains several provisions which are applicable specifically within the Sami Homeland area.

In the Sami Homeland, ${ }^{73}$ the holder of the ore prospecting permit must notify the owners of real estate included in the ore prospecting area and other rights holders in advance of all work on the terrain that could cause any damage or harm, and the erection of any temporary structures. Notification must also be submitted to the Sami Parliament, the appropriate local reindeer owners' associations within an area specifically intended for reindeer herding as stipulated in the Reindeer Husbandry Act (a special reindeer herding area), and to a village meeting of the Skolt people in the Skolt area referred to in the Skolt Act. ${ }^{74,75}$ Special notification rules apply also during after-care measures in an exploration area in the Sami Homeland: the notification by the ore prospecting permit holder shall not only be submitted to the mining authority, the owners of the properties included in the ore prospecting area and other holders of rights, but also to the Sami Parliament, to the appropriate local reindeer owners' associations in a special reindeer herding area, and/or to a village meeting of the Skolt people in the Skolt area. ${ }^{76}$ Gold washers in the Sami Homeland must provide advance notification in writing to the authority or institution responsible for management of the area, to the Sami Parliament, to the appropriate local reindeer owners' associations in a special reindeer herding area, and/or to a village meeting of the Skolt people in the Skolt area. ${ }^{77}$

The mining authority shall inform the following parties about the final inspection of a gold panning area: the gold washer and the authority or institution responsible for management of the area; within the Sami Homeland, the Sami Parliament; within 


\section{T. Koivurova et al.}

the Skolt area, the Skolt village meeting; and within a special reindeer herding area, the local reindeer owners' associations. ${ }^{78}$

The Act contains special provisions related to procedures to be applied in the Sami Homeland, Skolt area, and special reindeer herding area. "In the Sami Homeland, the permit authority shall - in co-operation with the Sami Parliament, the local reindeer owners' associations, the authority or institution responsible for management of the area, and the applicant - establish the effects caused by activity in accordance with the ore prospecting permit, mining permit, or gold panning permit on the rights of the Sami as an indigenous people to maintain and develop their own language and culture and shall consider measures required for decreasing and preventing damage. In such a case, the following shall be taken into account: any corresponding permits valid in the vicinity of the area referred to in the application; to which areas key to the rights of the Sami as an indigenous people the application pertains; other forms of usage of areas interfering with the rights of the Sami as an indigenous people in the area that the application involves, and in its vicinity." 79

The above provisions shall also apply to those projects implemented outside the Sami Homeland having considerable significance as regards to the rights of the Sami as an indigenous people. In the Skolt area, the permit authority shall request a statement from a Skolt village meeting concerning their assessment of the effects of activity under the permit on the sources of livelihood and living conditions of the Skolt people. ${ }^{80}$ In a special reindeer herding area, the permit authority shall, in cooperation with the local reindeer owners' associations, assess the damage caused to reindeer herding through activity covered under the permit. ${ }^{81}$

If necessary, the permit authority may arrange an event in order to clarify the matter, to which representatives of the Sami Parliament; the Skolt village meeting; the Skolt Council; the local reindeer owners' associations concerned; the applicant; the authority or institution responsible for management of the area; the local authority; and representatives of the local fishing area and forests in joint ownership are invited for consultation. ${ }^{82}$

The Finnish Mining Act sets up obstacles to granting a permit in case the planned activity endangers Sami rights. An ore prospecting permit, mining permit, or gold panning permit must not be granted if activities under the permit:

1. alone, or together with other corresponding permits and other forms of land use would, in the Sami Homeland, substantially undermine the preconditions for engaging in traditional Sami sources of livelihood or otherwise to maintain and develop the Sami culture;

2. would substantially impair the living conditions of Skolts and the possibilities for pursuing a livelihood in the Skolt area;

3. in a special reindeer herding area, would cause considerable harm to reindeer herding.

However, a permit may be granted regardless of an impediment referred to in subsection 1 if it is possible to remove such an impediment through permit regulations. ${ }^{83}$ 
Even already granted permits contain provisions that are necessary to ensure the status of the Sami as an indigenous people. The ore prospecting permit, the mining permit and the gold panning permit shall all include the necessary provisions for ensuring that activity under the permit will not endanger the status of the Sami as an indigenous people in the Sami Homeland, or the rights of the Skolts in accordance with the Skolt Act in the Skolt area. ${ }^{84}$

The Act prescribes an obligation to inform the Sami Parliament about a permit decision in case the decision involves the Sami Homeland. In these cases, a copy of the decision shall be submitted to the Sami Parliament, the Skolt village meeting, or to the local reindeer owners' association(s). ${ }^{85}$ In the case of final inspection, the mining authority shall inform the Sami Parliament in the Sami Homeland, the Skolt village meeting in the Skolt area, and the local reindeer owners' associations in a special reindeer herding area. ${ }^{86}$

The mining authority may prohibit a party that violates the Act or an order issued under it from continuing or repeating the procedure in breach of the regulation or order. ${ }^{87}$ The Sami Parliament has the right to initiate proceedings against activities having a detrimental impact in the Sami Homeland, unless such proceedings have been instituted on the mining authority's own initiative. ${ }^{88}$

Furthermore, special right of appeal is guaranteed by the Mining Act in order to protect Sami rights and interests:

A decision on an ore prospecting permit, mining permit, or gold panning permit; a decision to extend the validity of said permit; a decision on its expiry, amendment, or cancellation; or a decision to terminate mining activity may be challenged by way of an appeal by the following:

5) the Sami Parliament, on the grounds that the activity referred to in the permit undermines the rights of the Sami as an indigenous people to maintain and develop their own language and culture. ${ }^{89}$

According to the Russian Constitution and the Federal Laws, the rights of indigenous minority peoples to traditional natural resource use is a part of the human right to a favourable environment and an essential part of the human right to life. ${ }^{90}$ However, the Russian Federal Law "On Subsoil""91 does not mention any rights of indigenous minority peoples concerning resource extraction on their territories. The Law "On Subsoil" contains only one reference to numerically small indigenous peoples. Article 4 (10) states that the protection of the numerically small peoples' interests in the process of using mineral resources is the responsibility of regional authorities. This means that priority is given to commercial interests and not to indigenous peoples. ${ }^{92}$

According to the general view, the mining sector does not have an impact on the Sami in Russia, as mining activities are conducted elsewhere. All of the mining enterprises of the Kola mining complex were founded in the 1930s-1950s. It was a period of intensive development for the region, accompanied by a growth of population due to the inflow of migrants from other regions of the USSR. The Sami, 


\section{T. Koivurova et al.}

indigenous people of the Murmansk region, were forced into collectivization. As a result they were transferred to sedentary life and relocated to larger settlements. Such policy towards indigenous peoples was carried out in all regions of the Russian North. Consequently, certain settlement and management systems of Sami people were formed by the late $1960 \mathrm{~s}$ and are still in place. ${ }^{93}$ According to the Russian legislation, three municipal areas (Lovozerskiy, Kolskiy and Terskiy) and one urban district (Kovdor) of the Murmansk region have the status of a territory which is a traditional place of inhabitance and economic activity of indigenous numerically small peoples of the North. ${ }^{94}$ These areas cover $70 \%$ of the Kola Peninsula. ${ }^{95}$ Such status is awarded to a territory through Government Decree, based upon a proposal of the regional administration. The legislative norms of the Russian Federation towards indigenous numerically small peoples of the North are applied only to territories possessing such status. Thus, most mining enterprises of the Kola mining complex operate outside those territories having an official status of Sami land. The question of those territories that the Sami lost during the Soviet period is not discussed in Russia.

However, according to Professor Vladimir Kryazhkov, the Russian legislation is vastly inadequate when it comes to relations between mining companies and numerically small indigenous peoples. Of particular concern is the lack of the right of numerically small indigenous peoples to the lands they occupy. There is a need to develop the mechanism for interaction between mining companies and indigenous minority peoples in the Russian North. The mechanism should include, inter alia, carrying out ecological and ethnological expert examinations before commencing any commercial project on the lands of numerically small indigenous peoples. ${ }^{96}$

Generally we can conclude that although current legal documents in Russia are directed to improve the living conditions of indigenous minority peoples, often their rights and freedoms are not realized because of the absence of appropriate material and financial maintenance and strong control from the state. ${ }^{97}$

\section{An assessment of how much legal protection traditional Sami livelihoods have against the impacts of mining}

It seems obvious that there are stark differences between the four respective national legal systems, as to how much legal protection they provide for Sami traditional livelihoods against adverse mining impacts. This is a complex question to answer, since there are plenty of legal rules that protect both Sami traditional livelihoods and mining interests. Yet, what seems possible is to examine relevant questions from the perspective of each of these four legal systems.

In Russia, traditional indigenous livelihoods are given strong protection in principle. Several pieces of legislation aim at protecting Sami traditional livelihoods. In Finland, the protection of Sami reindeer herding is closely related to the cultural protection that the Sami Homeland region enjoys. It is those reindeer herders within the Sami Homeland region that are the Sami that enjoy most protection from the adverse impacts of mining. This is due to many factors. First and foremost, the new 
Finnish mining code takes into account the Sami indigenous rights very well, not only in their homeland region, but also as regards to those mining activities that may cause adverse impacts to the homeland region.

In Norway, the legal protection of reindeer herding differs between regions. However, Sami can also bring their claims of immemorial use to be studied by the Finnmark Commission..$^{98}$ Thus, even if it is debated whether the implementation of ILO 169 is satisfactory, reindeer husbandry in Norway enjoys fairly strong protection, ${ }^{99}$ guaranteed not only within the Finnmark area, but also in other relevant territories. ${ }^{100}$

In Sweden, one has to be a member of a Sami village to be able to do reindeer herding. Since reindeer herding is practiced over vast tracts of land in Sweden, there is an inevitable land use conflict since mining interests are also protected. ${ }^{101}$ Reindeer herding activities are to some extent protected by the Environmental Code where land and water areas of particular interest for reindeer herding shall be protected as far as possible, or, in the case of national interest, shall be protected against activities that may significantly hamper reindeer herding. However, land and water areas that contain valuable minerals enjoy the same protection and areas can thus be of particular as well as national interest for both activities. In such a case, the one that best promotes a sustainable development shall be "granted" the area (if a combination is not possible). The criteria for assessing the suitability of the use of the areas are rather vague and do not offer very clear guidance. The provisions do not offer protection in the typical sense, but are rather aimed to steer clear of activities that may hamper or interfere with designated land use interests. Moreover, the designation of national interest is not legally binding, so the interest that "wins" will have to be settled in the licensing process by the proper authority. It does however have some impact on municipal planning as municipalities have to take national interests into consideration in their spatial planning activities. ${ }^{102}$

Some areas in Sweden, such as certain mountain areas, enjoy a permanent position of national interest because of their natural and cultural values. In these areas, building and construction may only be allowed if necessary with regard to reindeer herding activities, and only if it does not cause significant damage to the area. This protection is stronger than that previously described since it is legally binding and is more precise in terms of substantive provisions. However, exceptions can be made, and of particular interest here is that the protection does not apply if the area holds deposits of valuable minerals, which, if special reasons are at hand, can still be extracted. ${ }^{103}$ "If there are special reasons, the provisions do not preclude facilities for the extraction of these deposits of substances or materials referred to in Chapter 3, section 7, second paragraph." Hence, there is a certain "edge" for mineral extraction over other activities, and the balancing of these various interests usually ends in favor of the mining activity. For instance, in the Rönnbäcken case the Swedish Government found in its balancing that the mining activity has an interest that prevails over reindeer herding. The Government also stated that even if reindeer herding is not possible in the areas in question if priority is given to the mining activities, it does not necessarily mean that the possibilities of the Sámi community to 


\section{T. Koivurova et al.}

pursue reindeer herding elsewhere are hampered. The affected Sami community then brought the case to the United Nations Committee on the Elimination of Racial Discrimination. Until the consideration of the petition, the Committee requested the Swedish State to suspend all mining activities in the area. ${ }^{104}$

\section{Does theory work in practice?}

In order to provide effective protection for Sami people, it is essential to examine whether the legislative framework is implemented well enough. By comparing the practices of different countries, the advantages and disadvantages of their regulations are highlighted, so benefitting future legislative changes and judicial practice. Authors aimed at shedding light on the current effectiveness, as well as the future perspectives of mining on Sami lands from the viewpoint of the mining sector, and how Sami themselves reflect to that. In order to find out how the legislation works in practice, ${ }^{105}$ semi-structured interviews were conducted with mining companies, environmental impact assessment consultants, representatives of respective authorities, and Sami representatives. The aim was to draw a realistic picture about the actual effectiveness of the legislation, based on the first-hand experience of the relevant parties involved in mining processes. Interviews were conducted in all of the relevant countries: Finland, Sweden, Norway and Russia.

\subsection{Finland}

In Finland, we conducted interviews with mining company representatives, EIA consultants, and representatives of relevant authorities. Although there is currently no mine in the Finnish Sami Homeland, the experts were asked to express their opinion on prospects and future possibilities. ${ }^{106}$ Despite our extensive efforts to secure interviews with the Finnish Sami Parliament, we unfortunately obtained no response. Also, several possible interviewees claimed that only the Sami Parliament, more precisely the president thereof, is entitled to give authoritative answers concerning such issues. Therefore, we had to draw conclusions based on available Sami Parliament statements. Unlike, for example the Norwegian Sami Parliament, the Finnish Sami Parliament seems to be opposed to any mining activity other than traditional gold panning.

Interviewees agreed that for companies, it is a very important factor whether the site is located on an area within the Sami Homeland. Obviously, a company needs to earn the social license to operate and has to take into consideration the impact on local people and culture. Therefore, some of the interviewees shared the opinion that the strong legal protection of the Sami can hinder companies who apply for permits in these areas. ${ }^{107} \mathrm{~A}$ Sami appeal is highly expected in most cases, and as companies would rather not risk lengthy court proceedings, they tend to plan their activities in areas which would pose fewer barriers. ${ }^{108}$ Moreover, besides the Sami interests, there are other important factors impeding mining in the northernmost part of Finland. These include national parks, wilderness reserves, and Natura 2000 areas, and tourism and the rights of local people have to also be carefully taken into account. 
Due to the lack of big deposits, there are currently no mining sites in the Finnish Sami Homeland. Therefore we asked our interviewees to imagine a scenario in which a rich deposit would be found in the Sami Homeland. The representatives of mining actors presumed that in such a case, companies would try to apply for permits but would be concerned about the outcome. ${ }^{109}$ The bigger the company, the more sensitive it is to indigenous rights issues, however, at the same time it is more likely to have well established ways of negotiating with local communities. ${ }^{110}$ Big international companies with experience in consulting with indigenous peoples in other countries would be less worried than either smaller companies, ${ }^{111}$ or companies that have been previously unsuccessful in trying to establish effective communication with indigenous peoples. ${ }^{112}$ Smaller companies might not even initiate the application process, due to the high probability of appeal. In the case of a smaller deposit being found, many companies would not try to apply for permits. ${ }^{113}$

Representatives of the mining companies all emphasized the importance and value of Sami culture and heritage. They all understood that mining may be seen as posing a threat to those values, and moreover, the question of mining is only a further addition to the already sensitive situation concerning the insecurity of land and cultural issues. The fundamental differences between these interests make it difficult to measure the impacts and benefits of mining on Sami lands and the impacts such activity would have upon their culture. ${ }^{114}$ It was however acknowledged that decisions cannot always be made solely on the basis of scientific facts, especially when there are strong traditions, emotions and politics in the background. ${ }^{115}$

Nevertheless, it was further argued by the parties that there is a growing demand to maintain the present lifestyle of the wider society, and minerals are essential for this purpose. The Lapland region has already proven to be rich in deposits; therefore the Sami Homeland area is most probably not an exception. Consequently, a growing pressure to mine on indigenous lands can be expected in the future. ${ }^{116}$

All interviewees agreed that more advanced consultations would help in many cases, however, dialogue alone cannot solve the whole problem. ${ }^{117} \mathrm{~A}$ better cooperation between companies and the Sami Parliament would certainly be needed. Although public hearings are the most important platforms for discussing the viewpoints of different parties, several actors have complained about the Sami Parliament not sending representatives to those hearings. Because of the lack of "face-to-face" consultations between companies and the Sami Parliament, there is no chance to discuss the opinion of each party and come up with a solution that is mutually beneficial. ${ }^{118}$ In many cases the Sami Parliament sends a formal opinion and subsequently rejects the planned activity. All interviewees agreed that one of the biggest problems is a lack of dialogue aimed at finding consensus. ${ }^{119}$ Interestingly, Sami individuals are not always against mining and some companies had even had experiences where Sami people had thanked them for initiating dialogue and giving them a better understanding of their activities. ${ }^{120}$

The majority of the people interviewed see the lack of clarity in the Finnish regulation as posing the core problem. ${ }^{121}$ The wording of the Mining Act is in many cases too general and therefore it is difficult to predict the potential future of a permit 


\section{T. Koivurova et al.}

application. Obviously, companies aim at acting in full accordance to the rules in order to obtain permits, especially in sensitive mining-issues, and would rather not risk long and insecure procedures. National and international rules concerning mining activities would need to be well-clarified in order that companies would be less hesitant to plan their activities in Sami areas. Better defined criteria for appeal would also be essential for ensuring more security for companies, and regulation on land issues and compensation would need further clarification from the Sami point of view. $^{122}$

Furthermore, many actors have expressed the opinion that the new Mining Act is "too new to work properly yet." ${ }^{123}$ One of the most significant changes in the new Act was the transfer of the mining authority from the Ministry of Employment and Economy to Tukes, ${ }^{124}$ however, the new authority has not yet gained enough experience in dealing with mining issues. Therefore, authorities and other relevant parties are also in the process of learning the new permit system. ${ }^{125}$ The Sami Parliament also confirmed this in its statement on their view on the implementation of the Mining Act in the Sami Homeland. ${ }^{126}$ They also claimed that there was a lack of explanation of what criteria Tukes uses to assess the effects on Sami culture.

Importantly, the people interviewed concurred in seeing the role of the media as one of the most pressing problems. ${ }^{127}$ Since the majority of media organs generally picture mining as being only a harmful activity, people tend to have a negative attitude towards mining. This is especially true in the Arctic, where people are more sensitive about environmental issues, mostly due to climate change and the relatively strong protection of indigenous peoples. In order to gain people's acceptance, our interviewees suggested that they would also have to be provided with more knowledge on the advantages (as opposed to only the disadvantages) of such activities.

Unfortunately, it is not only the wider public who have false or incomplete information on the real effects of mining activities. The Sami themselves are also struggling with this problem. As these activities have a significant impact on their culture, traditions and everyday life, the lack of information necessarily leads to misunderstandings between them and the mining companies. ${ }^{128}$ The interviewed representatives think that if the Sami were properly informed about the real effects of mining activities, they would probably be more co-operative and willing to allow mining to take place. Besides understanding the obvious fact that mining does harm the environment, the Sami would need more knowledge on the precautionary measures taken by companies. Most of our interviewees emphasized the importance of honesty towards local inhabitants, as it is essential in order to build trust. Some even went so far as to state that companies are in some cases perhaps more hesitant to plan activities in Sami areas than they should be, provided that they communicate honestly with the local people. ${ }^{129}$

Better information flow and co-operation would help to abolish the current misleading stereotypes, i.e. that mining companies are harmful actors in the Sami Homeland, and the reputation of Sami people in appealing against most types of mining activities. ${ }^{130}$ 
As previously mentioned, the fact that deposits may be located in the Sami Homeland does not, per se, hinder companies from a permit application if the company has enough experience in engaging in dialogue and negotiation with indigenous peoples. ${ }^{131}$ Obviously however, this dialogue must be initiated at the earliest possible stage of the planning process, and any communication with the local people must not only be honest, but also transparent. ${ }^{132}$

Most actors agreed that despite the possible threat imposed by mining on their culture and heritage, the Sami would need to see and understand that the mining industry does not only bring harm and threat to their lives, it can also be highly beneficial for the community. ${ }^{133}$ For instance, it would provide the possibility for young Sami to stay in their home area rather than moving to cities in order to secure a living. ${ }^{134}$ According to a mining company representative, although mining is a significant change for a municipality, such changes are not necessarily changes for the worse - as has been clearly proven by the operation of two mines in Sodankylä. ${ }^{135}$

According to the majority of experts, the most important step forward would probably be to allow more exploration activities in the Homeland region. ${ }^{136}$ The lack of information on the bedrock and possible deposits is currently one of the most problematic issues for companies. ${ }^{137}$ By allowing more exploration, more data could be provided, and based on such knowledge it would be easier to decide whether it would be worth planning any kind of mining-related activities on Sami lands. Furthermore, the Sami would still have the right to appeal in several later phases. ${ }^{138}$

Mining activities on Sami lands do however exist in other countries and this clearly indicates that it could be possible to conduct such activities on indigenous lands. Examples taken from these countries might also have an effect in Finland. For instance, the harsh reaction of Swedish Sami to mining operations might result in companies being reluctant to take steps in order to mine within the Homeland in Finland, for fear of similar reactions. ${ }^{139}$

Following the interviews conducted in Finland, there have been interesting developments in the mining industry. International mining companies have made hesitant steps towards mining in the Sami Homeland area. It is important to note that in Finland mining companies can take preparatory actions and reserve an area that they might be interested in exploring. This can be done by submitting a notification to the mining authority (reservation notification ${ }^{140}$ ) before applying for an exploration permit, or having an actual mining permit for the establishment of a mine and the undertaking of mining activities. ${ }^{141}$

Karelian Diamond Resources ("Karelian") ${ }^{142}$ has made reservations in the North of Finland, working in cooperation with one of the world's largest mining company, Rio Tinto Mining and Exploration Limited ("Rio Tinto"). ${ }^{143}$ Lately, Karelian has extended its activities to the Sami Homeland, more specifically to the Utsjoki area, and was granted an exploration Claim Reservation from Tukes in September 2014. ${ }^{144}$ The Claim Reservation grants exclusive rights to apply for exploration claims in the area for two years. The diamond search area is located in the Utsjoki river valley, partially extending to the Kevo Strict Nature Reserve. A big part of it lies 


\section{T. Koivurova et al.}

in a protected Natura 2000 area. Naturally, Sami traditional livelihoods like fishing and reindeer herding are being practiced in the area.

The actions of Karelian Diamond Resources encountered cross-border resistance, even before the actual reservation phase. The possibility of a mine is seen as a threat to Sami culture and heritage, as well as to the local community. Activists have gained strong support from Norway because of possible transboundary impacts. ${ }^{145}$ Experiences from the Kallak case ${ }^{146}$ in Sweden have been put to a use, ${ }^{147}$ and the lack of dialogue between the local people and the mining company has been notable. ${ }^{148}$ According to a company representative, they are open for discussions, however the initiation of dialogue at such an early stage of the planning seems to be rather pointless and the company does not want to raise false hopes. ${ }^{149}$

According to a mining official, it seems to be relatively easy for mining companies to make the first steps in planning mining activity and to get a reservation permit from the mining authority. Strong legal protection of Sami rights does not hinder companies' actions, however this seems to bring a further addition to the already sensitive situation concerning the insecurity of land and cultural issues. The reason for this is that the mining authority has the ultimate power to decide on the matter in a situation where the obligation to negotiate with Sami people does not apply ${ }^{150}$; the Court of Appeal has so far decided not to investigate one of the appeals made by the Sami organization, as it is not considered to be a litigant in the case. ${ }^{151}$

\subsection{Sweden}

In Sweden, mining on Sami territories is a highly disputed topic. The issue gained huge international attention in 2013, due to the so-called Kallak case. The test mining of iron ore in the Swedish Sami village of Gállok (in Swedish Kallak) provides an example concerning the interface between mining and Sami rights. Kallak is located in Northern Sweden in the municipality of Jokkmokk, where the mining site is located on reindeer grazing lands. These lands have been used by the Sami since time immemorial and the lands play a key role in Sami reindeer herding. The Swedish government has not only given test mining permission to a British owned company-Beowulf - but also sent police to protect mining equipment from attacks by the local people. Granting mining permission on these lands has had various adverse consequences on the local Sami, in terms of both their livelihood practices as well as other land use and resource practices. The mining location expects to place the Luleå River at risk of pollution, thus affecting the river's water quality. Therefore the Sami have been strongly resisting these developments by way of active demonstration and road blocking. Clashes between government forces and Sami activists brought mining issues up in the discussions regarding Sami rights within Sweden, in response to emerging mining activities which are perceived as affecting indigenous livelihoods and culture.

According to a survey of the Fraser Institute ${ }^{152}$ published in March 2014, Sweden currently has the most attractive jurisdiction for mining investment worldwide. Hence, more and more mining activities are expected to be initiated. Therefore, it is also essential to try to settle mining disputes involving indigenous lands. Our 
Swedish interviewees were asked about the current situation and their possible recommendations to improve co-operation between the mining companies and the Sami people in Sweden. Again, interviews were conducted mainly with actors of the mining sector: mining company representatives, authority representatives, mining experts, as well as Sami representatives.

There are several thousand valid permits which have been issued on Swedish territories, most of which are exploration permits. ${ }^{153}$ Less than $0.5 \%$ of these lead to the exploration of a deposit that could be extracted, and even less lead to an actual mine. ${ }^{154}$ The global financial crisis is also an important factor in relation to today's mining activities, as it significantly affects the whole mining sector. Given the fact that these activities are expensive to carry out and economic circumstances are far from being currently favorable, many of the companies are experiencing financial difficulties. $^{155}$

The Swedish legislation does not make any distinction between "Sami lands" and "non-Sami lands." However, as has been discussed, Sami interests such as reindeer herding have to be taken into account during the permit applications. ${ }^{156}$ For instance, the company has to show in its application that it is possible to continue reindeer herding, even whilst the mine is in operation. ${ }^{157}$ Other than that however, it is no more difficult to obtain a mining permit on a territory that is affected by Sami traditional livelihoods, than for a non-Sami territory. Sami, just like other landowners, can appeal against the decisions of the Mining Inspectorate of Sweden. ${ }^{158}$ However, as the Inspectorate is strictly bound to follow the provisions of applicable legal instruments in its proceedings, in most cases there are no legal grounds to win the appeal made against its decisions. Therefore, in the experience of the interviewees from the mining sector, the Sami focus more on trying to influence the work plan. During this phase they can determine with the company, for example the best timing of the planned activity, so as to cause the least possible harm for reindeer. $^{159}$

In practice, some of the Sami villages have realized that it is beneficial for them to try to co-operate with companies. There has been a case where a Swedish mining company managed to establish a special agreement with the Sami villages affected by its activities. The content of the agreement cannot be disclosed, however, it is known that it regulates inter alia the ways in which they provide each other with relevant information. For instance, Sami villages inform the company of all kinds of their activities in different parts of the affected area. This helps the company to measure the cumulative effects of its operation, which is especially important when trying to expand. The agreement also contains provisions for future cases. This is important for both parties, as it is highly expected that the company would extend its activities in order to meet the growing need for minerals. ${ }^{160}$ According to the representative of the company, they have established fruitful discussions with the Sami villages and managed to gain their trust. One reason for this is that the company has been operating on those territories for more than a century, hence the Sami have become used to its presence. The Sami villages would however probably be less willing to cooperate with a new company, and it is important to mention that the company has 


\section{T. Koivurova et al.}

tried to establish similar agreements with newly affected Sami villages, but as of yet unsuccessfully.

Sami protests against mining generally start as early as the exploration phase, however, the concordant opinion of the experts is that the situation would be clearer and easier if a defined area was presented. In this case companies would know whether it is in their interest to plan any other activities, and the Sami would know whether they have "anything to protest against." Unfortunately, according to general thinking if a company is exploring an area, it already means that there will be a mine in that location. ${ }^{161}$ The reality however is contrary - only a small part of exploration activities eventuate in exploitation and an even smaller part of those result in an actual mine. Similar to views expressed in Finland, the Swedish interviewees also agreed that the media influences mining related thinking in a negative way. ${ }^{162}$ Some of the experts also suggested that with the use of more effective technology it would be possible to predict the quality of the explored deposit without causing significant harm to the environment. ${ }^{163}$

Mining is also a current political issue in Sweden and was much debated in the campaigns preceding the Swedish national elections in the fall of 2014 . Besides the possibility of ratifying ILO Convention 169, mining-related fees and taxes also featured high on the political agenda. Since 2005, an annual fee has to be paid to the landowner and the state, based on the production of the company. Because of this, the attitude of landowners towards companies has definitely changed, and some of the experts suggested that the tension between companies and the Sami could be eased if local communities and reindeer herding villages received a part of this fee. ${ }^{164}$ Another suggestion to compensate for the loss of new areas is that companies would restore old mining sites. ${ }^{165}$

Our experts emphasized the importance of a relatively new provision in the Swedish legislation. Namely, that companies have to provide information on their economic security, and insure that they have enough money to cover damages caused by their operation. The reason for introducing this rule was an unfortunate case where a company went bankrupt and was unable to pay the adjudicated compensation to a Sami village. ${ }^{166}$

Opinions on the Kallak case are obviously controversial. According to some opinions, the protest is more a symbol of a political fight than a focused protest. It is a continuation of a series of other protests (by non-Sami) against mining that have been carried out over a three year period. This time however, the protests took place on territories that are important for the Sami, and presented them with a good opportunity to join the campaign. ${ }^{167}$ The company operations certainly stopped for a while. Some claim that the reason for this was the strong Sami protest, ${ }^{168}$ however other experts agree that the operations were mainly delayed for financial reasons. ${ }^{169}$ It is also important to note that several interviewees complained about the company failing to properly communicate with the Sami villages, and therefore the public hearings related to the case had no meaningful results. ${ }^{170}$

In general, the Sami consider their protest in Kallak to be fairly successful. They have tried to discuss the issue on different levels, so people would get more 
information on the current situation. The debate was even taken to the highest levels in politics. In their opinion, an important aspect of the problem is that the majority of young and educated Sami left their homes. The ones who stayed behind either have no time to protest or do not want to be involved with politics. Also, only a very few of them are aware of the actual rights and tools they have to fight for their interests. ${ }^{171}$ There are however cases such as the Pajala mine where Sami villages did not oppose (or not so strongly) mining activities, but some have expressed their concern that other companies would also want to operate on their lands. ${ }^{172}$

The fight for their culture and traditions against mining is rather costly for the Sami. They have tried unsuccessfully to get financing for their campaign. Moreover, Sami communities have even had to sometimes pay large amounts of money for environmental impact assessments (EIA), when they have decided to conduct new procedures having been unable to accept the EIA report commissioned by the company. Nevertheless, some success stories also give hope to the Sami. For instance, they managed to bring a case to the UN Committee on the Elimination of Racial Discrimination, after the Swedish court system deemed mining to be more important than reindeer herding. ${ }^{173}$ Generally, these are the two competing national interests in mining cases, ${ }^{174}$ however the majority of the interviewed experts agreed that the Sami often do not express a clear and realistic idea of what exactly they would like to achieve. ${ }^{175}$

\subsection{Norway}

In Norway, in 1994 the international mining company Rio Tinto Zink got permission from the Norwegian state to search for diamonds and minerals on Sami land in Karasjok. Being only a few years after the foundation of the Sami Parliament and Norway signing ILO 169, such permissions were given without informing Sami users of the land. However, Ole Henrik Magga, President of the Sami Parliament stood up and read a declaration for the company known as the first Sami resistance against mining. His words that the Sami people have not given permission to conduct this activity, scared off the international mining companies, and they were not to return for the next decade. ${ }^{176}$

The legal protection of Sami interests in mining has lately been tested in the case of two new planned mining projects in the Finnmark region; Nussir in the Kvalsund municipality and Arctic Gold in Kautokeino. They both pinpoint the conflicting interest of traditional Sami livelihood-predominantly reindeer herding - and mining, and also illustrate the important role of the Municipality in securing the interests of the Sami people.

The Norwegian investment company Nussir wants to develop an old copper deposit in Kvalsund municipality, a small coastal community with previous mining experience dating from the 1970s. The deposit is huge, and tailings from the mine are planned to be deposited in the national salmon fjord Repparfjorden, together with a considerable amount of chemicals. ${ }^{177}$ The traditional fjord Sami livelihood of fishing and farming has over a long period decreased ${ }^{178}$ and led to outmigration. This has weakened the Sami identity in the local community. The mining company went into 


\section{T. Koivurova et al.}

early dialogue with local residents and reindeer herders forming "Resource groups," and arranged several public meetings. ${ }^{179}$ Despite these efforts, several protests were put forward during the work of preparing the zoning plan and the EIA-process including the conditions of reindeer herders with summer and spring pastures which would be lost in the proposed development. However, the environmental interests and consequences of the sea deposit were more vocal in the debate and united several NGOs, fishing organizations and recreational interests. Nevertheless, the municipality was positive to the mine and as a planning authority passed the zoning plan. ${ }^{180}$ The reindeer herding district, together with the Sami Parliament objected to the plans. ${ }^{181}$ Mitigations with the company failed and the case was first brought to the Governor level, and then to the State level for decision. Four different Ministries considered the case, and finally in March 2014 the Ministry of Local Government and Modernization approved the zoning plan. This case shows that the protection of the Sami livelihood was set aside, and the utilization of the mineral resources and positive local ripple effects of the mining activity were considered more important. The objections from the reindeer herders and the Sami Parliament were not given sufficient attention. One sentence ${ }^{182}$ in the decision has nevertheless been questioned:

... the mining company must consult with the reindeer herders to implement remedial measures that secure the continuation of reindeer herding in the area. This must take place before the mining activity can be implemented.

The Sami Parliament has also questioned the way the Ministry tries to escape the obligations of international law. ${ }^{183}$

It is important that the reindeer herders are not forced to accept a decision they cannot live with. I find it strange that the Minister leaves the responsibility for fulfilling the obligation of international law to protect reindeer livelihood to a mining company.

Nussir has made some amendments to the plan in respect to the requirements of the reindeer herders. The most important are to plan an underground mine, not to take too much grazing land, and to construct less open roads and more tunnels. ${ }^{184}$ The later negotiations nevertheless failed to reach an agreement as none of the remedial measures proposed by the company could compensate for the loss of land. Representatives from the reindeer herders said ${ }^{185}$ : "If the interventions from the mine will be so severe that the reindeer herding in the area must stop or be considerably reduced, then this will be a violation of both national and international law, among others Article 27 in the UN International Covenant on Civil and Political Rights." It is obvious that the parties will not reach an agreement, and it is unclear how the process will develop further and to what extent the Norwegian State will intervene. This challenges the principle of the Norwegian State as being responsible for fulfilling the commitments of international and national law towards the Sami.

In the other case, Arctic Gold in Kautokeino is a Swedish investment company planning to reopen a gold mine in Biedjovaggi, an important reindeer territory. 
Mining in this area closed down in 1991, but increased market prices have again made this deposit interesting. Kautokeino municipality has a 95\% Sami population, and the Sami identity and protection of the traditional reindeer livelihood is strong.

The company started the process of preparing the zoning plan needed for the EIAprocess in 2010 and presented the first draft of the planning program to the relevant planning authority, the Kautokeino Municipal Council. Comments from different stakeholders were implemented in the revised planning program after a public hearing, and the Municipal Council took the case up for political decision. The Council, however, decided to completely dismiss the program. ${ }^{186}$ The argument was that the Council knew the consequences of mining from previous experience, and need no EIA. ${ }^{187}$ By refusing the planning program, the municipality gave a clear signal to national and international actors with an intention to make major interventions in the municipal territory. This was made possible due to the new paragraph included in the Planning and Building Act that gives the municipality the authority to "protect the natural basis for Sami culture, economic activity and social life."188 This implies that the Municipality considered the effect of mining to be adverse to Sami traditional livelihood, particularly reindeer herding. The Municipal Council wanted to protect the present users of the land, the reindeer herder's future existence, and to give a clear signal to the Government that intervention in reindeer herding land has reached a critical level. ${ }^{189}$

This was a totally unexpected turn for the company, and the first time that the new "Sami paragraph" of the Planning and Building Act had been used. The Arctic Gold company engaged a legal expert to test the legality of rejecting the proposal and the Municipality asked for legal advice from the Ministry of Environment and the Ministry of Justice. The legal investigation concluded in favor of the municipality:

Under doubt we have reached the conclusion that a municipality probably does not have an obligation to determine a planning program for a private planning process when the project is not wanted by the municipality. ${ }^{190}$

Nevertheless, a newly revised planning program was presented to the Kautokeino Municipal Council in December 2013, only to be once more refused by the politicians. A young representative of the Municipal Council said ${ }^{191}$ :

Today's decision will be important for both my and future generations ... An EIA is the first step to a permit for mining activity. I do not need to read EIAs to understand the nature of mining activity.

It is obvious that the Municipal Council of Kautokeino took the responsibility to protect the livelihood of its own reindeer herders against mining, and the Norwegian State found it difficult to object to the local decision.

We will not overrule the decision of Kautokeino Municipal Council. ... We shall listen to local democracy, and a majority of the Municipal Council has voted against a mine in Biedjovaggi. We will not proceed with this case. ${ }^{192}$ 


\section{T. Koivurova et al.}

The reindeer herders in Kvalsund did not experience such a degree of municipal support for their livelihood, probably because they are not permanent residents in the municipality and reindeer herding is not considered as an important part of the general municipal identity. Other competing Sami livelihoods were also at stake, but were not very vocal in the debate. It should be noted that these two mining cases have been looked to be implemented in Sami communities of different strengths, and ended with different outcomes. These two cases also illustrate the role of the Norwegian state and to what extent national mining interests are given priority over the protection of Sami livelihoods.

Much discussion has also emerged on the issue of taxation and fees to municipalities and the Sami Parliament from the mining industry. The law and tax system favor the state budgets. A frequent question asked by potential mining municipalities is: "What's in it for us?" Little of the value creation of mining activities stays in the local communities, and they are left with severe environmental effects, as well as a possible short term development that will halt when the company has depleted the resource. This has been discussed in both mining cases, but there is no national framework for distributing profit derived from the mining industry back to the local communities where they operate. This must be negotiated on a bilateral basis. Kvalsund municipality has negotiated for two years without being able to reach an agreement with the mining company. A municipal representative has said: "We want to establish a fund for business support by receiving $1 \%$ of the turnover of the mine," 193 however the company representative we interviewed was not supportive of this idea, and said that previous mining experience has illustrated that it is more important to focus on the development of the company, and not on the distribution of values yet to be created. ${ }^{194}$

This analysis has illustrated that the legal protection of Sami traditional livelihoods in Norwegian laws related to mining activity is quite good on paper. Most important are the Minerals Act, the Planning and Building Act, the Reindeer Act and the Finnmark Act. Sami interests can be brought forward in the different planning stages of new mineral projects and have the possibility to influence the process. This possibility is more evident in the Finnmark region compared to the rest of the country, where the Sami Parliament has the authority to make an objection. When it comes to the question as to whether these theories actually work in practice, the answer is not so clear. The Norwegian State can still decide that the national interests of the mining industry are more important than the interests of traditional Sami livelihoods. In the case of Artic Gold, the Norwegian State accepted the possibility of the Kautokeino Municipality to stop planning process of a mine. However, the Nussir mining case has yet to be brought to a final conclusion and will test the Norwegian State's responsibility for protecting the future livelihoods of reindeer herders.

\subsection{Russia}

The Murmansk region is one of most developed mining areas of Russia. There are large deposits of ferrous, non-ferrous, rare earth and precious metals, rock products 
(phosphate, ceramic and mica raw materials) and different construction materials found in the Kola Peninsula. The reserves of most raw materials are of national significance, while the reserves of apatite-nepheline and cyanite ores and rare earth metals have global significance. Nowadays a powerful mining complex is located in the Murmansk region, which includes enterprises of the mining and chemical industry, ferrous and non-ferrous industries and construction materials production. These enterprises focus on the extraction and primary processing of raw materials. The Kola mining complex is of great economic and social value for the Murmansk region. It plays an important role in the economy of North-West of Russia and the country as a whole, and is integrated into global economic relations. All mining enterprises in the region are backbone enterprises in one-company towns, and their financial and economic situation defines to a large extent the state of industrial and socio-economic infrastructure within the towns, as well as the state of employment and welfare for most of the local population. ${ }^{195}$

To analyze the interactions between the Sami and mining companies in Russia, the Lovozero district of the Murmansk region was chosen as a case study. Three groups of informants were defined for interviewing: representatives of the mining industry; Sami residents of the Lovozero district, and experts at local and regional levels.

The majority of the Kola Sami live in the Lovozero district of the Murmansk region (55\% of the total amount and $70 \%$ of the rural Sami). The reindeer herding industry of the Kola Peninsula is localized to this district, with the main pastures and two large reindeer farms "Tundra" and "Olenevod" being located here. ${ }^{196}$ At the same time, the Lovozero district is a mining area and there is a large mining and processing enterprise in the area. The Kovdorskiy GOK has been operating since 1952 and is an important economic backbone for the whole district. The enterprise includes two operating mines and an industrial site for ore dressing. ${ }^{197}$ Moreover, there are rich reserves of minerals including rare metals and alumina in the district. According to regular geological surveys, there are several promising fields, some of which are included in the State record (i.e. with potential for development). ${ }^{198}$ The interviews showed that there are currently two models of interaction between the Sami and the mining sector, depending of the type of the enterprise.

\subsubsection{Old "Soviet" enterprises}

Our interviews show that there is a stable opinion in all groups of respondents that the existing enterprises do not do any harm to the Sami. The resettlement and loss of territories are perceived by Sami and other informants to be a result of the Soviet policy in general, and not the development of mining in the region. According to the State regional organization The Center of Indigenous Peoples of the Murmansk Region, no cases of direct harm to the indigenous people were registered and no complaints were submitted from the population (representatives of the numerically small indigenous people of the North) about the activities of mining enterprises.

The representative of the local authorities supposed that the mining sector does not have any impact on indigenous peoples, even from the point of view of the 


\section{T. Koivurova et al.}

environment,because the Lovozerskiy GOK is located far from the areas used by the Sami:

The Sami territories and industrial areas do not overlap. The indigenous people do not have complaints and claims about the mining enterprise: it is our backbone enterprise and the chief employer in the district. It means our income and work places. The Sami also work there."199

The opinion of the mining sector representative was that the issue of the company's interrelations with the indigenous peoples is not urgent at all.

We do not have any problems with the Sami. The issue is not urgent. I do not know about the whole of Russia, but our enterprise does not have such problems. We have few common points. There is a long distance between the company's areas and the Sami territories. Our mines are located in the mountains which are not suitable for being pastures. We do not impact on the environment of the Sami territories as we have only underground mines, which can be used even in nature reserves and parks. $^{200}$

Due to the fact that the Russian mining legislation does not include any provisions related to indigenous peoples, the enterprises do not bear any responsibility towards them:

The relations with the Sami are not regulated in any way. We do not have any responsibilities to them. We have Sami employees and they work the same as all the others. We do not ask people for their nationality. People from all over the world work here: Tadjiks, Sami, Ukrainians, etc. We do not have any professional training or employment programs for the Sami. All work on an equal basis. ${ }^{201}$

This company is not planning any expansion or the development of new deposits, so the company management is not afraid of possible conflicts in the future.

We are far from each other. Even if the company expands its production, it will not touch the pastures. The Sami do not have any complains about us. We do not bother them in any way. We do not impact their lives and the reindeer herding. ${ }^{202}$

On the whole, the interaction of the company and the Sami is point-like and comes down to sponsor assistance in various cultural affairs, organized by the Sami organizations.

We love the Sami. We help them. We financially back the North Festival for example, and other affairs. The local administration provides a request for financing and we always try to assist and participate, though our company is not rich. We cooperate with the "Tundra" farm ${ }^{203}$ and buy their products and milk for example. ${ }^{204}$

At the same time there is an opinion among experts that the cooperation of the leading companies in the region and the local population should be more active and efficient. This relates not only to those territories which have the status of the traditional place of inhabitance and economic activity of the numerically small indigenous people of the North, but to the whole mining complex of the Kola Peninsula:

There is some cooperation but its level is low. It is desirable to reach a closer, systematic and continuous cooperation. Companies could develop a Sami 
cooperation program following the example of the company "Sakhalin-energy," which developed and is now realizing an Action plan for the development of indigenous minorities of the North in the Sakhalin region. ${ }^{205}$

Such statements are general and advisory. The issue of cooperation between mining companies and the indigenous people in the region is not seriously discussed, and this applies to all companies, including those located in territories which lost their status of traditional Sami territories in Soviet times. The issue of resettlement or compensation for these lands is also not discussed.

\subsubsection{New promising projects}

It is greatly feared that the development of new deposits will have a significant impact on the indigenous population. Such activities may also induce environmental damage and do harm to the pastures.

There are no development projects at the moment. But in case they begin (for example in the Caves), there will be consequences: new roads will appear in the tundra, all this will impact the nature. What is most important is that people will come to the tundra, it means poaching and a worse environment. ${ }^{206}$

There is a general belief among the population and experts that the opinion and interests of the Sami should be taken into consideration during the realization of mining projects and at the earliest stages. There are prerequisites for this: first, there are facilitating instruments, and second, that there is good experience available.

The existing legislation does not provide for special mechanisms to consult with Sami interests in mining projects, though this can be done within the framework of consultations with local communities. The production license is awarded by the Ministry of Natural Resources. An exception is raw materials which are "in common use." These are mainly construction materials and come under control of the regional authorities. ${ }^{207}$ To start the work, it is necessary to go through a procedure of State expert review which is carried out by a special federal state committee (except for deposits of regional significance when the committee is regional). The company applying for the field development delivers the results of the preliminary EIA to the committee. ${ }^{208}$ Before prospecting, companies apply to local authorities for burden details of the territories intended for the development, and receives data about indigenous peoples, their points of residence and economic activities. ${ }^{209}$

The EIA may also include an ethnological review which brings to light and assesses the possible effects of the project on the indigenous population. According to Russian legislation, such a review is not obligatory for the company and can be organized on its own initiative. The general practice shows that serious companies, integrated into the global economy, and for example attracting foreign partners and using global financial instruments, tend to include an ethnological study into the EIA. Such companies usually belong to the oil and gas industry.

The indigenous population can also be consulted without a specific review. The Law of Environmental Review requires publicity as one of the principles of such a 
review, for example public hearings and the participation of public organizations. ${ }^{210}$ To fulfill this principle, the local authorities are empowered to:

- delegate their own public experts to participate in the expert committee;

- organize public hearings for projects and public enquiries;

- organize at the demand of the population, a public EIA conducted by public organizations, the results of which should be taken into consideration during the state expert review. ${ }^{211}$

The use of public hearings as an instrument of collaboration between the business, authorities and the population have recently become widespread and welcomed by all participants in the process. Both the population and the authorities consider this to be an effective instrument and encourage its use:

The interests of the Sami are taken into consideration: there are public hearings, where one can give an opinion and have public discussions of problems. ${ }^{212}$

On the whole, the numerically small indigenous peoples of the North and the population of the Lovozero district follow the situation and actively participate in public hearings; they do not hesitate to express their opinions and concerns. ${ }^{213}$

One of the examples of active interaction between a mining company and the Sami has been the development project of "Fedorova Tundra" in the Lovozero district. The Fedorova Tundra is a complex deposit of copper, nickel and platinum-group elements. The exploration and production license currently belongs to Fedorovo Resources ZAO, established by the Canadian gold mining company Barrick Gold (one of the largest gold mining companies in the world), and to the Russian geological prospecting enterprise Pana JSC. The project implies the deposit development by two mines with a total annual capacity of no less than 12 million tons of ore. The final product should be a concentrate containing copper, nickel, gold, platinum and palladium ready for further dressing. The construction of a processing plant is planned to produce ore concentrate. At present however, the project is frozen due to economic circumstances. ${ }^{214}$

The company performed some intensive work and research in the deposit area between 2007 and 2008, including coordination with local community and indigenous population interests. Community liaison offices had been working for two years and the local population could receive information about the projects and share its suggestions and views. Several open public discussions were organized. Special attention was paid to reindeer herding and in particular, an agreement with reindeer farms was achieved about the construction of barriers around the pastures. Specialists from other regions of Russia were invited to coordinate the projects, together with Sami interests. Training courses were organized for the representatives of the numerically small indigenous peoples of the North, to teach them how to make applications for the financing of social projects and how to further compete in such projects. On the initiative of the local population, the construction of a playground and repairs to a local school were also financed. ${ }^{215}$ 
According to the representatives of the mining complex, Fedorova Tundra is a unique project and untypical for the Murmansk region. The focused attention paid to the local community is explained as being the initiative of the Canadian project partners. ${ }^{216}$ At the same time however, the local population and experts consider such a practice to be obligatory.

There should be coordination in all issues. If there is no coordination, there will not be any development. The companies will organize consultations with the public because the population may retard the process. ${ }^{217}$

There is a belief that the negative attitude of the Sami and their objections may change the plans of a company and thus bring them to a halt. So, companies are interested in coordinating their interests. Emphasis should be placed upon reindeer herding, as it is the main economic activity of the Sami. Experts suppose that it is not difficult to communicate with the local population if the company is interested in doing so. However, a lot depends of the company's attitude:

It is not difficult to have a dialogue. People attend to such affairs. Dialogue is possible. It is possible to achieve the congruence of interests in several ways. If companies want, they will find opportunities. Much depends on the situation. It is possible to agree on the first try. If it doesn't happen, the company needs to demonstrate its willingness to long-term cooperation. To my mind, some activities aimed at improving living conditions for the people and investments into the district will be effective. ${ }^{218}$

At the same time all respondents were sure that despite existing cooperative practice, the mining complex will be prioritized during the development of any new projects.

The fact that a deposit is located on the Sami territories will not stop a company. It will nevertheless apply for a production license. The existence of numerically small minorities of the north will be taken into consideration and the company's plans will probably undergo some correction, but the decision is made on a federal level and national interests will be prioritized. That which is more profitable for the economy will be developed. The main factor on behalf of the Sami is, naturally, the pastures. But they can be removed and decreased, etc. If companies do not develop a deposit, presently, it is likely to be due to some economic reasons. It has nothing to do with the Sami. ${ }^{219}$

The fact that the lands of the Murmansk region are federal makes things worse, in that the decisions are taken by the Ministry of Natural Resources. The pastures are also federal territories and the reindeer farms lease the lands for a long term period. Local authorities and the population cannot influence the decision making process at the federal level.

Russian mining legislation does not have any provisions for the defense of rights of indigenous peoples and these issues are regulated by special legislation. Thus, legal consultations with the Sami during the development phases of mining activities are not organized in Russia. The Sami participate in the discussions devoted to specific 
laws, and notably, the opinion of those indigenous people who have participated in such discussions was that the process is not well enough organized; for instance the time limits suggested for the inquiry and proposals are very tough and do not let issues to be dealt with to a sufficient level. ${ }^{220}$

According to the indigenous population, the legal framework of Russia on the whole corresponds with their interests and provides enough instruments for the defense of their rights, although the practical application of such mechanisms is difficult.

Our legislation is OK, especially the federal one, but when it comes to the interests of specific groups of local people, there are no mechanisms to defend their rights locally. It is difficult to influence anything locally. The local authorities and the local population need more power. ${ }^{221}$

Nowadays, local administrations do not participate in resource allocation and allocation is not regulated at the municipal level. As the lands are mainly federal, decisions are taken at a federal level. As a rule the public hearings are seen as a formality, but people should actively participate in the decision making process. $^{222}$

On the whole, there are legal instruments for the defense of rights. There is the legal framework, too. But the people are passive and there are no specialists. There is a lack of special knowledge on how to use these instruments. The youth leave the area and is not interested in the development of the territory, but the elderly people lack the knowledge. ${ }^{223}$

According to the local authorities, there has never been any proceeding about the defense of the rights of indigenous peoples related to mining projects in the district (or in the general region). The main instruments for the defense of Sami rights are the consultations held with companies and public hearings. At the time of writing, there were no mining projects under development, and the instruments are not seen to work.

There are no plans for field development in the near future. There were consultations for the Fedorova Tundra project. There was an agreement with the local administration and public organizations. There were meetings and negotiations. A support fund was established (books published and supported activities, etc.), but it was long time ago and now the project is frozen. ${ }^{224}$

The main document proving that the local community agrees with the conduct of mining operations on their territory is a Protocol of the public hearings, which is signed by local authorities. Public organizations insist that they also have a right to participate in the signing procedure. Sami organizations have such a possibility also, but no special documents for coordinating the interests of the Sami and mining companies are foreseen.

As a conclusion on the Russian situation, we can say that the mining sector in the Kola Peninsula consists mainly of large and established (operated from 1950-60s) 
companies. The relationship between these enterprises and the Sami evolved during the Soviet time, when the interests of indigenous peoples in Russia were not considered. In general therefore, the Russian mining sector is in the process of changing the "Soviet legacy."

It is generally believed that the mining sector (and in particular the old companies) does not influence either the Sami livelihood in general, or reindeer husbandry in particular, because their territories do not overlap. The Sami have not expressed any claims to the mining companies. The mining companies and Sami have minimum communication, although for instance, the Lovozerskiy GOK supports Sami festivals as a sponsor. One of the most important problems for the reindeer herding industry is that geologists working in the pastures often violate the soil whilst conducting their operations, and this issue is poorly regulated. ${ }^{225}$

There are apprehensions among the Sami and local authorities that the development of new deposits can have major consequences. However, from the mining and geologist perspective the prospects for any development of new fields in the Lovozero district in the near future is quite low for economic reasons.

Currently, special arrangements to involve Sami in mining projects, including any EIA or SIA (environmental/social impact assessment) are not established. Their interests are considered within the framework of common procedures for local communities. However, for territories of traditional habitation, this question is important and merits obligatory discussion.

Both Sami and the authorities believe that the development of new mining projects will include the discussion of Sami interests, and there is positive experience to be seen in the "Fedorovo Resources" and "Stockman" developments. In general though, Sami people suppose that such discussions will be formal and the interests of mining will prevail.

Russian mining legislation does not regulate Sami relationships and these issues are regulated by special federal legislation. In general, the Sami consider federal legislation to be sufficient, but they note that local legislation works poorly in practice. The Sami expectations from mining companies are rather low, taking the form of support for cultural events, funding for local infrastructure, etc. Issues such as the return of territories lost in the Soviet time, or any compensation for them are not discussed.

\section{Conclusion}

Due to the growing global demand for minerals, the related extension of mining activities, and the fact that indigenous lands are often rich in natural resources, these territories are generally threatened by extractive industries. The tensions between indigenous rights and the economic interests of states is therefore obvious. The Arctic - and Fennoscandia in particular - is known for its rich mineral deposits, therefore Sami rights related to mining activities require special protection. Based on the above findings, it can be noted that the effectiveness of mining legislation related to indigenous rights raises concerns for many of the parties. 


\section{T. Koivurova et al.}

The article studies the relevant national legislation and the protection of Sami rights therein. The legal protection that the Sami people now enjoy against mining and its adverse impacts is relatively strong, however it is very different in the four countries with Sami population. The aim of conducting interviews with mining companies, consultants, authorities, experts and Sami representatives was to compare the effectiveness of this protection. Obviously, none of the legislation of the four countries is ideal, therefore one can hardly decide which one gives the most protection. Norway is the only country from the region that has ratified ILO 169 Convention, and also its main mining act contains specific provisions for the Finnmark area, thus we can state that the level of protection is fairly high, especially in Finnmark. In Finland, the new Mining Act provides a strong level of protection for the Sami within the Sami Homeland. Although in principal Swedish Sami have the same status as other landowners, their rights have recently been strengthened. Here, it is important to bear in mind that in Sweden and Norway reindeer herding is the exclusive right of the Sami. Tensions seem to be less serious in Russia, where mining territories and reindeer herding areas do not overlap each other.

Given that indigenous rights need to be protected, but the mining industry also needs to extend, it is important to establish appropriate standards set by the legal and social-cultural norms, respecting the rights and values of indigenous peoples. An important initiation is the Nordic Sami Convention, ${ }^{226}$ aiming to clarify the difficult legal situation and provide a comprehensive framework for regulating the legal relationship between the Sami and the three Nordic states. ${ }^{227}$ To show the importance of the issue, the Convention contains a separate chapter about Sami rights to land and water, and also a chapter about Sami livelihoods. Furthermore, specific provisions ensure protection against mining by regulating the negotiations between authorities and the Sami, and by prohibiting mining activities on relevant territories without the consent of the Sami Parliament and those Sami who are affected. ${ }^{228}$ Although the negotiations are still pending, the approval of the Convention might further harmonize the three Nordic system, vis-a-vis adverse mining impacts. ${ }^{229}$

\section{NOTES}

1. The special status of the Sami as an indigenous people is guaranteed in the highest level of law - the Constitutions of Norway, Finland, Sweden and Russia.

2. The core of the research was conducted under the "Sustainable Mining, Local Communities and Environmental Regulation in Kolarctic Area" (SUMILCERE) project. Among other research questions, the project, funded by the Kolarctic ENPI CBC initiative of the European Union and being run within the period of 2013-2014, focuses on mining and indigenous rights in the Kolarctic region.

3. Our research group has conducted 24 interviews in total.

4. Especially salmon fishing and snare trapping for grouse had extensive economic significance for previous generations.

5. Josefsen, Eva. The Sami and the National Parliaments: Channels for Political Influence. 2010, 5. http://www.ipu.org/splz-e/chiapas10/saami.pdf (accessed September 15, 2014).

6. Seurujärvi-Kari, Irja, et al., The Sami the Indigenous People of Northernmost Europe. Brussels: European Bureau for Lesser Used Languages, 1997, at 21. 
7. Hansen, Lars Ivar. "Tax, Trade and Diversification among the Northern Sami during the 16th Century". In Transference. Interdisciplinary Communications 2008/2009, ed. Willy Østreng. Oslo: CAS, 2010.

8. Josefsen, The Sami and the National Parliaments, 5.

9. Seurujärvi-Kari et al., The Sami the Indigenous People, 18.

10. Thuen, Trond. "Culture as Property? Some Saami Dilemmas" . In Properties of Culture Culture as Property. Pathways to Reform in Post-Soviet Siberia, ed. Erich Kasten, 87-108. Berlin: Dietrich Reimer Verlag, 2004.

11. Naykanchina, Anna. "Indigenous Reindeer Husbandry-The Impacts of Land Use Change and Climate Change on Indigenous Reindeer Herders' Livelihoods and Land Management, and Culturally Adjusted Criteria for Indigenous Land Uses”. 2012, 17. http://reindeerherding.org/wp-content/uploads/2013/01/UNPFII-2012-Reindeer-Husbandry_ Final23Nov.pdf (accessed September 15, 2014).

12. The Sami People. http://thornews.com/2012/08/07/the-sami-people/ (accessed September 15, 2014).

13. Almost 70,000 year round and 20,000 in winter.

14. 20,700 year round and approximately 38,000 in winter. More information at: www. sametinget.se

15. More information at the website of Swedish Geological Survey: www.sgu.se

16. Sami fjord fishing is a livelihood with less attention, and with decreasing employment due to national regulations and fishing rights. Similar to fjord fishing, Sami farming is also hard to distinguish from farming conducted by non-Sami. However, the number of farms and farmers in the Sami areas shows a decreasing tendency.

17. Article 9 of the Reindeer Husbandry Act.

18. Article 32 of the Reindeer Husbandry Act.

19. Number of people on the register granting permission to conduct reindeer herding. The full time equivalent is less than 1000. Reindriftsforvaltningen. Totalregnskap for reindriftsnceringen, 2013. http://www.reindrift.no/asset/6786/1/6786_1.pdf (accessed January 19, 2015).

20. The inland areas are used in winter, the coastal areas in the summer. The land in between is used in the autumn time during the mating season, and in the spring during the calving season.

21. Fauchald, Ole Kristian. "Regulating Environmental Impacts of Mining in Norway". In ed. Gabriel Michanek. Nordisk Miljörättslig Tidskrift/Nordic Environmental Law fournal 1 (2014): 53-65.

22. However, it is important to note that the main indigenous reindeer herders in Russia are not the Sami, but the Nenets, Evenks and the Komi.

23. Thuen, "Culture as Property? Some Saami Dilemmas".

24. "Tundra" and "Olenevod" were created during the Soviet era as state farms. After privatization in the 1990 s, they are now functioning as joint-stock companies.

25. Indigenous small-numerical peoples of the North. Official website of the Government of the Murmansk region (in Russian). http://www.gov-murman.ru/natpers/centre/ (accessed January 26, 2015).

26. Sami Murmanskoy oblasti (po dannym Vserossiyskoy Perepisy naseleniy). Murmansk. Murmanskstat. 2013.

27. Vinogradova, Svetlana. "Rodovay obschina kak obschestvennuy institute (na primere kolskih saami)". In Gragdanskie initsiativy $v$ sfere etnicheskoy politiky. Vosmognosty posrednichestva grazdanskih struktur $v$ dele predupregdeniy $i$ uregulirovaniy etnicheskih konfliktov, eds. Vladimir Zorin and Valeriy Stepanov, 106-113.

28. Hansen. "Tax, Trade and Diversification among the Northern Sami", 48. 


\section{T. Koivurova et al.}

29. Seurujärvi-Kari et al., The Sami the Indigenous People, 19.

30. Hansen, "Tax, Trade and Diversification among the Northern Sami", 48.

31. The text of General Comment 23 is available at: http:/www1.umn.edu/humanrts/ gencomm/hrcom $23 . \mathrm{htm}$

32. See para. 9.3. Länsman et al. v. Finland, Communication No. 511/1992, U.N. Doc. CCPR/C/52/D/511/1992 (1994).

33. Ravna, Øyvind. "The Fulfilment of Norway's International Legal Obligations to the Sámi Assessed by the Protection of Rights to Lands, Waters and natural Resources". International fournal on Minority and Group Rights 21 (2014): 325-7.

34. Translation of Article 3-1 from Norwegian: Within the frame of $₫$ 1.1., shall plans according to this law.... c) safeguard the foundations of Sami culture, business and society. https://ovdata.no/dokument/NL/lov/2008-06-27-71/KAPITTEL_2-1-1\# KAPITTEL_2-1-1 (accessed January 19, 2015).

35. Article 5-4.

36. Traditional herding society.

37. For more information see also Heikkilä, Lydia. "Reindeer Talk - Sámi reindeer Herding and Nature Management". Acta Universitatis Lapponiensis 110 (2006): 98.

38. See also Allard, Christina. "Who Holds the Reindeer-Herding Right in Sweden? A Key Issue in Legislation". In The Proposed Nordic Saami Convention - National and International Dimensions of Indigenous Property Rights, eds. Nigel Bankes and Timo Koivurova, 207-27. Oxford, UK: Hart. 2013.

39. 1971:437, the text of the Act is available in Swedish at: http://www.notisum.se/Pub/Doc. aspx?url=/rnp/sls/lag/19710437.htm (accessed November 07, 2014).

40. Section 1 of the Reindeer Herding Act.

41. See also Allard, Christina. "Two Sides of the Coin: Rights and Duties". Doctoral diss., Luleå: University of Technology, Chapter 7, 2006.

42. Nordmaling case. Case No.T 4028-07, decided on April, 27, 2011. For more information see Allard, Christina. "The Swedish Nordmaling case". Arctic Review on Law and Politics, 2 (2011): 225-8.

43. Ratified by Government RF Decree of May 8, 2009 N 631-r.

44. The Law of the Murmansk region N 380-01-ZMO of 14.01.2003 "On Reindeer Herding in the Murmansk Region". Available online in Russian. http://base.garant.ru/16943802/ (accessed January 26, 2015).

45. Shortly referred to as: "On Guarantees".

46. Shortly referred to as: "On Territories".

47. Shortly referred to as: "On Obshchina".

48. Kryazhkov, Vladimir. A. Korennye malochislennye narody Severa $v$ rossiyskom prave, Moscow. NORMA, Moscow, 2010, 301-9.; Garipov, Ruslan. "Resource Extraction from Territories of Indigenous Minority Peoples in the Russian North: International Legal and Domestic Regulation". Arctic Review on Law and Politics 4, no. 1 (2013): 16; Zadorin, Maxim. "The Status of Unrecognized Indigenous Communities and Rural Old-Residents of the Russian Arctic". In The Yearbook of Polar Law Online, eds. Gudmundur Alfredsson, Timo Koivurova, and Adam Stepien, Brill (e-journal), 669-74. Vol. 5, no. 1, 2013; and UN Special Rapporteur, S. James Anaya. Report on the situation of human rights and fundamental freedoms of indigenous people, Situation of indigenous peoples in the Russian Federation, A/HRC/15/37/Add.5, 2010.

49. Resolution of the Government of the Russian Federation N 132-p of 04.02.2009 "On the Concept of Sustainable Development of Indigenous Peoples of the North, Siberia and the Russian Far East”. Available online in Russian. http://base.garant.ru/194908/ 
50. UN Special Rapporteur, S. James Anaya, Report on the situation of human rights and fundamental freedoms of indigenous people, Situation of indigenous peoples in the Russian Federation, A/HRC/15/37/Add.5

51. The Law of the Murmansk region N 984-01-ZMO of 30.07.2008 "On State support for Numerically Small Indigenous Peoples of the North, Conducting Traditional Economic Activities and Crafts in the Murmansk region". http://base.garant.ru/16958936/

52. The Law of the Murmansk region N 380-01-ZMO of 14.01.2003 "On reindeer herding in the Murmansk region". http://base.garant.ru/16943802/

53. Mining Act, 627/2011. English translation is available at: http://www.finlex.fi/en/laki/ kaannokset/2011/en20110621.pdf

54. Minerals Act, 1991:45.

55. Act of 19 June 2009 No. 101 relating to the acquisition and extraction of mineral resources (the Minerals Act). English translation is available at: http://www.regjeringen.no/upload/ NHD/Vedlegg/lover/mineralsact_translation_may2010.pdf

56. The Law of the Russian Federation "On Subsoil” - No 2395-1 (1992).

57. Chapter 3, Section 5 of the Minerals Act.

58. Information by the Mining Inspectorate in English can be found at: http://www.svemin.se/ MediaBinaryLoader.axd?MediaArchive_FileID=39fa 14b0-3c5c-4f50-a7d7-85191d12d80 e\&FileName $=140807$-information + Mining + Inspectorate-.pdf

The amended text is available in Swedish at: http://www.riksdagen.se/sv/Dokument-Lagar/ Forslag/Propositioner-och-skrivelser/Battre-information-och-tydliga (accessed November 7, 2015).

59. As the Sami Parliament does not see the Mineral Act as an appropriate instrument to regulate the relationship between Sami interests and mining companies, they worked out their own Mineral Guide in 2011. file://C:/Users/vigdisn/Downloads/The + Sami + Parliament $\%$ E2\%80\%99s + mineral + guide + (2010).pdf (accessed January 19, 2015).

The guidelines are a tool for promoting Sami culture, business and society in planning use of mineral resources. Further, it determines the expectations of the Sami parliament towards companies, and forms of cooperation with companies that wish to reach an agreement with the Sami parliament. One of the results were signing of bilateral letters of intent between the Sami parliament and three mining companies in Finnmark.

60. Section 2 of the Mineral Act.

61. Section 6 of the Mineral Act.

62. For more information on the discussion see also Ravna, Øyvind. "The Fulfilment of Norway's International Legal Obligations to the Sámi - Assessed by the Protection of Rights to Lands, Waters and natural Resources." International journal on Minority and Group Rights 21 (2014): 325-7.

63. Section 10 of the Mineral Act.

64. Chapter 4, Section 13 of the Mineral Act.

65. Section 18 of the Mineral Act.

66. Section 17 of the Mineral Act.

67. Introduction to the The Sami Parliament's mineral guide. Available online in English at: http://www.sametinget.no/Miljoe-areal-og-kulturvern/Energi-og-mineraler (accessed January 19, 2015).

68. \5-6 Regulations to the Minerals Act. In Norwegian. https://lovdata.no/dokument/SF/ forskrift/2009-12-23-1842 (accessed January 19, 2015).

69. This is supported by law expert Susann Funderud Skogvang (2010).

70. The text of the Strategy is available in English at: https://www.regjeringen.no/contentassets/ 3fe548d142cd496ebb7230a54e71ae1a/strategyforthemineralindustry_2013.pdf (accessed January 18, 2015). 


\section{T. Koivurova et al.}

71. Paragraph 4.9 .

72. Chapter 1, Section 1 of the Mining Act. See also Koivurova, Timo and Anna Petrétei. "Enacting a New Mining Act in Finland - How were Sami Rights and Interests Taken into Account?" In ed. Gabriel Michanek, Nordisk Miljörättslig Tidskrift/Nordic Environmental Law fournal 1 (2014): 119-33.

73. According to Section 4 of the Act on the Sami Parliament, the Sami Homeland means the areas of the municipalities of Enontekiö, Inari and Utsjoki, as well as the area of the reindeer owners' association of Lapland in Sodankylä. The Act is available online at: http:// www.finlex.fi/fi/laki/kaannokset/1995/en19950974.pdf (accessed May 16, 2014).

74. Kolttalaki 253/1995.

75. Chapter 2, Section 12 of the Mining Act.

76. Chapter 2, Section 15 of the Mining Act.

77. Section 27 of the Mining Act.

78. Section 30 of the Mining Act.

79. Section 38 of the Mining Act.

80. Provisions concerning the statement procedure are laid down in section 56 of the Skolt Act.

81. Section 38 of the Mining Act.

82. Section 38 of the Mining Act.

83. Section 50 of the Mining Act.

84. Sections 51,52 and 54 of the Mining Act.

85. Section 58 of the Mining Act.

86. Section 145 of the Mining Act.

87. Section 156 of the Mining Act.

88. Section 159 of the Mining Act.

89. Section 165 of the Mining Act.

90. Garipov, Ruslan. "Extractive Industries and Indigenous Minority Peoples' Rights in Russia". In ed. Gabriel Michanek, Nordisk Miljörättslig Tidskrift/Nordic Environmental Law fournal 1 2014: 72.

91. The main Law regulating mining activities in Russia.

92. Garipov, "Extractive Industries and Indigenous", 73.

93. Gutzol, Natalia, Vinogradova Svetlana and Samorukova Antonina. The Resettled Groups of Kola Sami. Apatity: KSC RAS, 2007, 89.

94. RF Governmental Decree of May, 8th 2009 No. 631-r approving the List of the territories of traditional inhabitance and economic activities of indigenous small numerical peoples of the Russian Federation and the List of traditional economic activities of indigenous small numerical peoples of the Russian Federation.

95. For reference: The Murmansk region includes 12 urban districts and 5 municipal districts.

96. Kryazhkov, Korennye malochislennye narody Severa, 301-9. Translation taken from Garipov, "Extractive Industries and Indigenous", 73.

97. Garipov, "Extractive Industries and Indigenous", 73.

98. For more information see also Ravna, Øyvind. "The Process of Identifying Land Rights in Parts of Northern Norway: Does the Finnmark Act Prescribe an Adequate Procedure within the National Law?”. In eds. Gudmundur Alfredsson and Timo Koivurova. Yearbook of Polar Law, 3 (2011): 423-53.

99. See UN Special Rapporteur James Anaya. "Report of the Special Rapporteur on the Situation of Human Rights and Fundamental Freedoms of Indigenous People". A/HRC/ 18/XX/Add.Y. Paragraph 49. Besides other legislation (such as the Finnmark Act), the Reindeer Husbandry Act of Norway provides strong protection for reindeer herding.

100. See for instance the Selbu case (21 June 2001), where the Norwegian Supreme Court stated that the Sami population of Norway, including the Southern Sami areas, is qualified 
beyond doubt for status as an indigenous people under Article 1b of ILO Convention 169/ 89. The Supreme Court emphasized the significance of Sámi cultural features, reindeer husbandry characteristics, migration patterns and land use when assessing rights acquisition. As a result, two reindeer husbandry districts acquired grazing rights within specified areas of the municipality of Selbu according to immemorial usage. For further information see also Ravna 2011 p. 429.

101. For more information on Sami territorial rights, see also: Allard, Christina. "The Nordic Countries' Law on Sámi Territorial Rights". Arctic Review on Law and Politics, no. 2, 2(2011): 159-83.

102. Chapter 3 of the Environmental Code.

103. Chapter 4, Section 1 of the Environmental Code.

104. For more information on the case see: Labba, Maria Kristina. "Mineral Activities on Sámi Reindeer Grazing Land in Sweden”. In ed. Gabriel Michanek. Nordisk Miljörättslig Tidskrift/Nordic Environmental Law fournal 1 (2014): 93-8.

105. For example, Finland and Sweden have been criticized by a report on the human rights situation in the EU for not providing efficient protection and not guaranteeing effective participation for the Sami. See also: Report on the Human Rights Situation in the European Union by the Ministry of Foreign Affairs of the Russian Federation. Moscow, 2013.

106. A part of the findings of these interviews has been published in: Koivurova and Petrétei, "Enacting a New Mining Act in Finland", 119-33.

107. Environmental consultant, interviewed 13.2.2014; Mining company representative, interviewed 14.2.2014.

108. Mining company representative, interviewed 14.2.2014.

109. Environmental consultant, interviewed 13.2.2014.

110. Environmental consultant, interviewed 20.2.2014; Mining company representative, interviewed 14.2.2014.

111. Environmental consultant, interviewed 20.2.2014.

112. For example, in Australia and South Africa.

113. Mining company representative, interviewed 14.2.2014.

114. Mining company representative, interviewed 11.2.2014; Environmental consultant, interviewed 13.2.2014; Mining company representative, interviewed 14.2.2014; Environmental consultant, interviewed 20.2.2014.

115. Environmental consultant, interviewed 13.2.2014.

116. Mining company representative, interviewed 14.2.2014; Environmental consultant, interviewed 20.2.2014.

117. Environmental consultant, interviewed 13.2.2014; Environmental consultant, interviewed 20.2.2014.

118. Environmental consultant, interviewed 13.2.2014; Mining company representative, interviewed 14.2.2014.

119. Some interviewees failed to see any solid and substantial reasoning of these formal opinions. For example, the Sami Parliament once argued that a company was at fault because it should have published their notification in the newspaper in the Sami language.

120. Mining company representative, interviewed 14.2.2014.

121. Representative of a relevant authority, interviewed 12.2.2014; mining company representative, interviewed 14.2.2014.

122. Mining company representative, interviewed 14.2.2014.

123. Environmental consultant, interviewed 13.2.2014.

124. Finnish Safety and Chemicals Agency (Turvallisuus- ja kemikaalivirasto), the mining authority in Finland. 


\section{T. Koivurova et al.}

125. Mining company representative, interviewed 14.2.2014.

126. Number of Statement: 584/D.a.9/2013.

127. Environmental consultant, interviewed 13.2.2014; Mining company representative, interviewed 14.2.2014; Environmental consultant, interviewed 20.2.2014.

128. Representative of a relevant authority, interviewed 12.2.2014; Mining company representative, interviewed 11.2.2014; Mining company representative, interviewed 14.2.2014.

129. Mining company representative, interviewed 14.2.2014.

130. Environmental consultant, interviewed 13.2.2014; Environmental consultant, interviewed 20.2.2014.

131. Environmental consultant, interviewed 20.2.2014; Mining company representative, interviewed 11.2.2014.

132. Mining company representative, interviewed 11.2.2014.

133. Environmental consultant, interviewed 13.2.2014; Mining company representative, interviewed 14.2.2014.

134. Environmental consultant, interviewed 13.2.2014.

135. Mining company representative, interviewed 14.2.2014.

136. Mining company representative, interviewed 11.2.2014; Representative of a relevant authority, interviewed 12.2.2014.

137. Representative of a relevant authority, interviewed 12.2.2014; Environmental consultant, interviewed 13.2.2014.

138. Mining company representative, interviewed 11.2.2014.

139. Environmental consultant, interviewed 20.2.2014.

140. Section 44 of the Mining Act.

141. The Finnish Safety and Chemicals Agency (Tukes). Gold Panning, Exploration and Mining. http://www.tukes.fi/en/Branches/Mining/ (accessed September 2, 2014).

142. Diamond exploration company, focused in Finland.

143. Karelian Diamond Resources. Lapland Diamond Exploration Claim Reservations Granted. http://www.kareliandiamondresources.com/news/files/2014/2014-June-4-LaplandClaim-Reservation-Granted.doc (accessed September 3, 2014).

144. The Finnish Safety and Chemicals Agency (Tukes). Reservation Permit VA2014:0052. http://www.tukes.fi/Tiedostot/kaivokset/Varauspaatokset/VA20140052_paatos_ja_kartta.pdf (accessed September 3, 2014).

145. Barents Observer. Lapland Diamond Plans Cause Cross-Border Pollution Concern 13.6. 2014. http://barentsobserver.com/en/business/2014/06/lapland-diamond-plans-cause-crossborder-pollution-concern-13-06 (accessed September 2, 2014).

146. See the next sub-chapter for more information on the case.

147. Sami representative, interviewed 3.9.2014.

148. Municipal Manager, Interview in the Program Spotlight. http://areena.yle.fi/tv/2205438? ref=leiki-arp (accessed October 10, 2014).

149. Mining Company Representative, Interview in the Program Spotlight. http://areena.yle.fi/ tv/2205438?ref=leiki-arp (accessed October 10, 2014).

150. Mining Official, Interview in a Program Spotlight. http://areena.yle.fi/tv/2205438?ref= leiki-arp (accessed October 10, 2014).

151. Court of Appeal in Northern Finland, Ruling 14/5215/1. 11.7.2014.

152. Internationally recognized research organization with a focus on mining. The survey is available online at: http://www.fraserinstitute.org/research-news/news/display.aspx? id $=20902$

153. Mining authority representative, interviewed 9.9.2014.

154. Mining company representative, interviewed 9.9.2014.

155. Mining authority representative, interviewed 9.9.2014. 
156. Mining authority representative, interviewed 9.9.2014; mining company representative, interviewed 9.9.2014.

157. Mining company representative, interviewed 9.9.2014.

158. The authority administering applications for exploration permits and exploitation concessions.

159. Mining authority representative, interviewed 9.9.2014.

160. Mining company representative, interviewed 9.9.2014.

161. Mining company representative, interviewed 9.9.2014.

162. Mining authority representative, interviewed 9.9.2014; mining company representative, interviewed 9.9.2014.

163. Mineral expert, interviewed 9.9.2014. One possibility would be the use of geometallurgy (the technical background necessary for this method is being developed.). For more information on geometallurgical methods see also: Lund, Cecilia and Pertti Lamberg. "Geometallurgy - A Tool for Better Resource Efficiency". European Geologist 37 (2014); and Lund, Cecilia, Mineralogical, Chemical and Textural Characterisation of the Malmberget Iron Ore Deposit for a Geometallurgical Model. Luleå: Luleå University of Technology, Universitetstryckeriet, 2013.

164. Mining company representative, interviewed 9.9.2014.

165. Mining company representative, interviewed 9.9.2014.

166. Mining company representative, interviewed 9.9.2014.

167. Mining authority representative, interviewed 9.9.2014; mining company representative, interviewed 9.9.2014.

168. Sami activist, interviewed 3.9.2014.

169. Mining authority representative, interviewed 9.9.2014; mining company representative, interviewed 9.9.2014.

170. Sami activist, interviewed 3.9.2014; mining company representative, interviewed 9.9.2014.

171. Sami activist, interviewed 3.9.2014.

172. Mining authority representative, interviewed 9.9.2014.

173. The individual communication submitted to the UN Committee on the Elimination of Racial Discrimination is available online at: http://www.sametinget.se/49821

174. Sami representative, interviewed 3.9.2014.

175. Mining authority representative, interviewed 9.9.2014; mining company representative, interviewed 9.9.2014.

176. TV recording of the speech. Available at: http://tv.nrk.no/program/SAPR67002114/defoerste-skritt-sametinget-gjennom-25-aarChapter 7 Rio Tinto Zink

177. Documentation of the resource and planned deposits can be found at webpage of the company: http://www.nussir.no/

178. Eytorsson, Einar. "Konsekvenser for sjøsamisk bruk av Repparfjorden og siønære arealer". NIKU oppdragsrapport 70/2011. http://www.nussir.no/environmental-pub/esia/NIKU Seasami ESIA Study N 30mar11.pdf (accessed January 20, 2015).

179. Interview with representative from the company, June 2014.

180. Interview with municipal representatives, December 2013.

181. List of commentary documents can be found on the company web page: http://www.nussir. no/en_enviro_zoning.php (accessed January 20, 2015).

182. Translation of a Letter to the Governor of Finnmark from the Ministry-26th March 2014. http://www.regjeringen.no/nb/dep/kmd/tema/plan--og-bygningsloven/plan/ kommuneplanlegging/innsigelsessaker/2014/Kvalsund-kommune---innsigelse-til-regulerings plan-for-Nussir-og-Ulveryggen.html?id=753930 (accessed January 19, 2015).

183. Translation of statement referred to on the Sami parliament home page 20 March 2014. http://www.sametinget.no/Miljoe-areal-og-kulturvern/Energi-og-mineraler/Ingengruvedrift-i-Nussir-selv-om-reguleringsplan-er-godkjent 


\section{T. Koivurova et al.}

184. Interview with company representative, June 2014.

185. Translation of interview in an article in NRK Sapmi. http://www.nrk.no/sapmi/ikke-enigeom-avbotende-tiltak-1.11898427 (accessed January 19, 2015).

186. 26th April 2012 and 16th December 2013.

187. Translation of the municipal resolution of 26th April 2012.

188. Planning and Building Act, $₫ 3-1$.

189. Translation of the municipal resolution of 26th April 2012.

190. Translation of letter, 5 July 2013.

191. Translation of media article NRK Sapmi, 16th December 2013. http://www.nrk.no/sapmi/ kautokeino-sier-nei-til-gruve-1.11420378 (accessed January 20, 2015).

192. Translation of statement of Minister of Local Government and Modernization, referred to in media article NRK Nordnytt, 25th March 2014. http:/www.nrk.no/nordnytt/ respekterer-kautokeinos-gruve-nei-1.11628425 (accessed January 20, 2015).

193. Translation of article, interview with municipal representative. http://www.finnmarkdagblad. no/nyheter/article7591925.ece (accessed January 20, 2015).

194. Interview with company representative, June 2014.

195. Murmanskay oblast v XX veke: tendensii, faktiry I problemy socialno-economicheskogo rasvitia - Apatity, KSC RAS. 2009. p. 8, 41.

196. Representative of the Center of the indigenous peoples of the Murmansk region, May 2014.

197. Representative of the Kovdorskiy GOK, May 2014.

198. Representative of Pana company, May 2014.

199. Representative of the administration of the Lovozero district, May 2014.

200. Representative of the Lovozerskiy GOK, May 2014.

201. Representative of the Lovozerskiy GOK, May 2014.

202. Representative of the Lovozerskiy GOK, May 2014.

203. Tundra farm - large agricultural company, focused on not only reindeer herding but also milk cattle breeding and processing of the natural products.

204. Representative of the Lovozerskiy GOK, May 2014.

205. Representative of the Center of the indigenous peoples of the Murmansk region, May 2014.

206. Representative of the Sami public organization, May 2014.

207. Law on licensing of economic activities of 08.08.2001 No. 128FZ; Law on Subsoil of 21.02.1992 No 2395-1.

208. Law on environmental expert review of 23.11.1995 No. 174FZ.

209. Representative of the administration of the Lovozero district, May 2014.

210. Law of Environmental Review, Article 3.

211. Law of Environmental Review, Article 9.

212. Representative of the administration of the Lovozero district, May 2014.

213. Representative of the Center of the Indigenous Peoples of the Murmansk Region, May 2014.

214. Representative of the Pana company, 2014.

215. Representatives of the companies Pana, Federovo Resources and the reindeer farm Tundra, May 2014.

216. Representative of Pana company, May 2014.

217. Representative of the administration of the Lovozero district, May 2014.

218. Representative of the administration of the Lovozero district, May 2014.

219. Representative of the administration of the Lovozero district, May 2014.

220. Representative of the administration of the Lovozero district, May 2014.

221. Representative of the Sami NGO- OOSMO, May 2014. 
222. Representative of the Public Organization of the Sami of the Murmansk Region, May 2014.

223. Representative of the Association of the Kola Sami, May 2014.

224. Representative of the Public Organization of the Sami of the Murmansk Region, May 2014.

225. Representative of the Public Organization of the Sami of the Murmansk Region, May 2014.

226. The text of the Convention is available online at: http://www.regjeringen.no/upload/BLD/ Nordic Sami Convention.pdf

227. For more information see Koivurova, Timo. "The Draft for a Nordic Saami Convention". In European Yearbook of Minority Issues, eds. Tim Dertwinkel, Emma Lantschner, 103-36. Vol. 6. Martinus Nijhoff Publishers, Netherlands, 2006/7.

228. Article 36 of the Convention.

229. The draft Nordic Saami convention tries to also include Russian Sami in various ways. See also Koivurova, Timo. "Draft for a Nordic Saami Convention: Nations Working Together”. International Community Law Review 10 (2008): 279-93. 